\title{
CIÊNCIANATURA
}

\section{A destruição da natureza em ambientes rurais e urbanos no Brasil - uma tragédia que ainda pode ser revista}

\author{
The destruction of nature in rural and urban environments in Brazil - \\ a tragedy that can still be reviewed \\ Cláudio Jorge Moura de Castilho ${ }^{1}$ Bruno Augusto Nogueira Monteiro Pontes², \\ Robson José Alves Brandão ${ }^{2}$
}

${ }^{1}$ Departamento de Ciências Geográficas e Programa de Pós-graduação em Desenvolvimento e Meio Ambiente, Universidade Federal de Pernambuco, Brasil

${ }^{2}$ Programa de Pós-graduação em Desenvolvimento e Meio Ambiente, Universidade Federal de Pernambuco, Brasil

\section{Resumo}

Este artigo possui como objetivo principal denunciar o processo permanente de destruição da natureza como tragédia no tempo-espaço, através de pesquisas realizadas em ambientes rurais e urbanos localizados no Nordeste brasileiro, no contexto atual de aceleração dos propósitos fundamentais de geração de valores como meta maior do capitalismo. A metodologia deste trabalho fundamentou-se numa abordagem relacional do processo de produção do espaço geográfico, considerando, principalmente, a inter-relação dialética entre as suas dimensões material e imaterial, configurando uma totalidade complexa em permanente movimento na história dos homens e das mulheres. A elaboração de mapas e de figuras representativas do objeto ora tratado foram procedimentos técnicos utilizados visando a reforçar a argumentação, a qual teve como resultado principal a defesa da ideia de que ainda é possivel reverter o atual processo de destruição da natureza, através da análise dos casos ocorridos em duas microrregiões localizadas no Oeste da Bahia e em uma área litorânea da Região Metropolitana do Recife.

Palavras-chave: Bioma Cerrado. Praia do Paiva. Racionalidade ambiental.

\section{Abstract}

This article aims to denounce the permanent process of the nature's destruction as a tragedy in the time-space, which is based on research carried out in rural and urban environments located in the Brazilian Northeast, in the current context of the acceleration in terms of generating values as a major goal of capitalism. The methodology of this work was based on a relational approach with regard to the process of geographical space's production, considering, mainly, the dialectical interrelationship between its material and immaterial dimensions, shaping a complex totality in permanent movement in the history of men and women. The elaboration of maps and representative figures of the object being treated were technical procedures used to reinforce the argument, which had as main result the defense of the idea that it is still possible to change the current process of nature's destruction, through the analysis of the cases occurred in two microregions located in the West of Bahia and in a coastal area of the Metropolitan Region of Recife.

Keywords: Cerrado biome. Praia do Paiva. Environmental Rationality. 


\section{Notas introdutórias}

Os homens e as mulheres, para serem e existirem no mundo, sempre se relacionam com a natureza, e nesta relação - dialética entre a "primeira natureza" ou "natureza natural" e a "segunda natureza" ou "natureza histórica inerentes à vida humana na Terra - não há como não impactar na natureza. Compreendemos, assim, a natureza como uma totalidade complexa resultante da junção entre tais dimensões inter-relacionadas entre si, formando uma teia que se movimenta permanentemente em algum sentido segundo às vicissitudes do tempo-espaço.

Porém, conforme a formação econômico-social e territorial sob a qual acontece a relação acima ressaltada, o resultado em termos de impactos ambientais dependerá da capacidade de controle dos impulsos destruidores da natureza fazendo valer, como dizia Brunhes (CASTILHO, 2017), as "forças sábias da natureza" as quais reordenam e regeneram o ambiente que é desmantelado; ou, por outro lado, do descontrole de tais impulsos pelas "forças loucas do sol" as quais desmantelam e desagregam os ambientes.

Em função, notadamente, da predominância dos imperativos da lógica da racionalidade técnico-instrumental capitalista hegemônica inerentes à formação econômico-social e territorial brasileira, engendrou-se, neste país, um conjunto de perversidades as quais, por sua vez, acham-se representadas pelo que se pode considerar como uma verdadeira tragédia cujos efeitos são mascarados pela linguagem dos discursos hegemônicos.

Para Castoriadis (1992, p. 62), “A 'racionalidade instrumental' dos indivíduos humanos é, a cada vez, socialmente instituída e imposta. [Ela] é impossível sem a linguagem. Ora, toda linguagem acompanha a totalidade do mundo social de que faz parte". A linguagem - a exemplo dos discursos do desenvolvimento rural pelo agronegócio e do desenvolvimento urbano pela intensificação do urbanismo empreendedor - constitui, portanto, um instrumento mediante o qual se reforçam os interesses hegemônicos, mascarando a verdadeira essência do processo de produção do espaço geográfico.

Estamos aqui utilizando o termo tragédia no seu sentido figurativo segundo o qual, de acordo com o Dicionário Aurélio da Língua Portuguesa, ela se refere a um "Acontecimento que desperta lástima ou horror; ocorrência funesta; sinistro [...]; desgraça, infortúnio” (FERREIRA, 2010, p. 2065), que é o que desperta em nós no momento em que percebemos a continuidade, no tempo-espaço, dos processos de destruição dos nossos ecossistemas e dos nossos povos, incluindo aqui os seus respectivos ethos.

Com efeito, no momento em que nos aproximamos da realidade entendendo-a como uma totalidade complexa e que, por conseguinte, verificamos como as atuais ações humanas - mais de caráter antropogênico - estão destruindo a natureza, passamos a sofrer com o que vemos e, por conseguinte, buscamos refletir sobre possibilidades concretas de rever esta postura destruidora da natureza, a qual, na verdade, destrói a nós mesmos. O que, acreditamos, pode suscitar uma outra linguagem, ou seja, uma linguagem capaz de reverter a consolidação da tragédia ora em andamento, achando-se aqui a possibilidade concreta de se rever a tragédia ambiental em curso.

Diante do que acabamos de colocar, adotamos e defendemos uma postura de ciência, efetivamente, dialógica com relação ao seu “objeto" de pesquisa, suplicando que se preste mais atenção à complexidade dos diversos processos de destruição-construção dos diversos ambientes vividos na Terra, aproximando-nos geograficamente deles e, principalmente, sem a pretensão de dominá-los.

Na sua pertinente crítica à ciência, Nietzsche (2013) não propôs eliminá-la, mas, ao contrário do que se disse sobre a ideia deste filósofo, realizá-la através do diálogo com o saber e, ao mesmo tempo, procurando respeitar o homem sem nenhuma intenção de dominá-lo. E isto no âmbito do acontecer da vida, o que remete a uma teia de sentimentos de simpatia, amor, prazer, desprazer, elevação, esgotamento. Do contrário as ciências provocariam efeitos barbarizantes na sociedade, ou seja, "Elas se perde[ria]m facilmente a serviço dos 'interesses práticos'. Valor de Schopenhauer, porque traz à memória ingênuas verdades gerais: ousa enunciar elegantemente pretensas "trivialidades"” (NIETZSCHE, 2013, p. 26)

Atualizando e consolidando esta perspectiva de ciência, por meio de uma postura mais radical contra a perspectiva vigente, Castoriadis (1992, p. 102) defendeu que, em vez de um conjunto de certezas, a ciência deveria ser um "objeto de paixão para o filósofo". Neste sentido, este pensador não deixava nenhuma dúvida de que o "cientista" deveria ser um

[...] poço interminável de enigmas, mistura inextricável de luz e obscuridade, testemunho de incompreensível encontro sempre garantido e sempre fugitivo entre nossas criações imaginárias e o que é. Também, como afirmação vibrante da nossa autonomia, da rejeição das crenças simplesmente herdadas e instituídas, da nossa capacidade de tecer constantemente o novo numa tradição, em nos transformar apoiando-nos sobre nossas transformações passadas.

Com vistas à superação da perspectiva hegemônica positivista de ciência, a tragédia também se tornou uma preocupação segundo a qual, no âmbito das discussões filosóficas, "O ponto de partida implícito ou explícito dessas discussões quase sempre é a definição aristotélica de tragédia segundo a qual ela é 'imitação de acontecimentos que provocam piedade e terror e que ocasionam a purificação dessas emoções' [...]. As situações que provocam 'piedade e terror' são aquelas em que a vida e a felicidade de pessoas inocentes é posta em perigo, em que os conflitos não são resolvidos ou são resolvidos de tal modo que determinam 'piedade e terror' nos espectadores". (ABBAGNANO, 2012, p. 1155)

De acordo, ainda, com este mesmo dicionário, a atualidade do pensamento acerca da tragédia residiria na necessidade de se manterem vivas as questões problemáticas na filosofia relativas ao próprio destino de sofrer que nos tem acompanhado no curso da nossa existência no mundo, bem como ao anseio permanente de redenção para além da utopia e do infortúnio. 
Na geografia, por vezes, a denúncia - e mesmo a superação - de questões relativas à tragédia na vida dos homens e das mulheres nos seus territórios de existência também constituiu uma preocupação, a qual se tem direcionado para a análise do sofrimento dos homens e das mulheres diante das distorções do seu mundo. O que tem fomentado argumentações tais como as realizadas por Raffestin (2015) e Vallerani (2013), por exemplo, reativando a perspectiva da "geografia de denúncia" que se fazia no início do movimento de reflexão acerca da sua filosofia e metodologia durante os anos 1960 e 1970.

No que concerne à primeira argumentação, destacamos que, na visão de Raffestin (201[?]), é preciso repensar as noções dos fenômenos não apenas na perspectiva da sua significação instrumental, o que não deixa de ser necessário, muito embora não seja suficiente; mas, ao mesmo tempo, na perspectiva de uma problemática relacional do homem no confronto com os obstáculos que, de uma certa feita, entravam a sua existência nos seus respectivos territórios.

Justificando sua ideia com base numa análise relacional entre "a fronteira e o sofrimento" de pessoas "separadas" pela insensatez dos conflitos bélicos, este pensador argumentou sobre a questão ora em discussão, ressaltando a necessidade de se recorrer a outros instrumentos de análise dentre os quais se utilizou da contribuição da arte para o entendimento da complexidade dos problemas territoriais dos povos. Desse modo, segundo o próprio autor,

[...] parei diante de uma escultura de Paolo Grassino [numa exposição realizada em 2007 em Turim] que representava o que estou tentando dizer neste escrito. A escultura representa um personagem impactante perfurado por barras de prisão: limite materializado que divide o corpo em dois, donde o título, sem dúvida, de semilibertà. Eu disse 'barras de prisão', na ausência de outro termo melhor, mas pode-se tratar de uma fronteira, que separa e quebra as comunidades e os homens que a elas pertencem. O efeito desta escultura é terrível, sofre-se com o personagem atravessado, penetrado, perfurado pelas barras de ferro por cada parte de seu corpo. Eu quero dizer, simplesmente, que [...] são os artistas que, pelas suas obras, precedem os especialistas em ciências sociais. [...] Quando os artistas desenvolvem um tema, trata-se de um indício de que este revela o sofrimento escondido ainda não explicitado plenamente no nosso cotidiano. (RAFFESTIN, 2015, p. 1-2, tradução livre)

Trata-se assim de uma tentativa de superar a dimensão morfológica dos fenômenos analisados visando apreender a estrutura que, apesar de se achar aparentemente invisível, pode ser observada quanto aos seus efeitos sobre os homens e as mulheres no momento em que os problemas que lhes afligem acontecem.

Quanto à segunda argumentação, também fazendo uso de manifestações da arte, destacamos a percepção de tragédias, como a ambiental, a partir do desenvolvimento da ideia de que sem os "geógrafos que sofrem com as paisagens" não conseguiremos nunca superar os problemas que afligem nossos ambientes de existência. Nesta perspectiva, segundo Vallerani (2013, p. 38),

Posso afirmar que a ânsia catastrófica revelou-se, para mim, como um inconsciente estratégico de defesa com relação a uma situação pior que poderia acontecer [...]. Esta espécie de reação mental foi-me útil visando ao prosseguimento do estudo da criticidade ambiental [...] garantindo-me igualmente um certo destaque no que diz respeito à coleta dos dramáticos testemunhos dos ativistas pela defesa da paisagem e da integralidade ecológica do território. Sofrer pelos dramas que aconteceram na paisagem determina um estado de angústia que é, porém, facilmente, compartilhado, suscitando ações cívicas de reação às ameaças ao bem comum.

E, também, à consciência de que se deve ter outras posturas com relação à gestão do território. O espaço não é, portanto, um "espaço vazio" a ser, como escreveu Moraes (1997), "permanentemente preenchido" de maneira autoritária e conservadora, sujeito a ações alheias às especificidades territoriais que lhes são inerentes. Mas, muito ao contrário, o espaço constitui uma totalidade complexa resultante da articulação das inter-relações dialéticas e dialógicas entre os objetos e as ações materiais e imateriais que se acham nele contidos, que se movimenta permanentemente em algum sentido (CASTILHO, 2017).

Daí por que qualquer ação no território usado pela sua sociedade em tempos diferentes promove impactos no que nele existe como conteúdo - solo, água, vegetação, umidade, pessoas, ethos, etc. -, razão pela qual sempre deve haver diálogo com base no respeito entre as ações humanas e os objetos encontrados no processo de relação entre sociedade e natureza.

Em face do exposto, o objetivo principal do presente artigo reside no fato de denunciar o processo permanente de destruição da natureza no tempo-espaço, através de resultados de pesquisas realizadas em ambientes rurais e urbanos localizados no Nordeste brasileiro, no contexto atual de aguçamento dos propósitos fundamentais de geração de valores como meta maior do capitalismo.

Com efeito, temos consciência de que, talvez, estejamos repetindo um problema que muitos outros pensadores já o indicaram. Neste caso, corroborando a visão de Castoriadis (1992, p. 77), vale a pena ressaltar que

Tudo já foi dito. Tudo sempre tem que ser dito de novo. Esse fato maciço, por si só, poderia levar ao desespero. A humanidade pareceria surda; e realmente não ouve o essencial. É esse o tema, antes de tudo, nesta discussão que versa sobre as questões políticas fundamentais. Tal é, para a humanidade moderna, a questão das relações entre seu saber e seu poder [...]. Não há relação. Há um poder - que é impoder quanto ao essencial - da tecnociência contemporânea, poder anônimo em todos os sentidos, irresponsável e incontrolável (pois não é suscetível de ser atribuído a quem quer que seja) e, por enquanto [...], uma passividade completa dos humanos (inclusive dos cientistas e dos próprios técnicos considerados como cidadãos). Passividade completa e mesmo condescendente diante de um decorrer de acontecimentos que os humanos querem crer ainda que lhes é benéfico, não estando mais completamente persuadidos de que tal benefício dure por muito tempo. 
No âmbito desta perspectiva, para atender ao objetivo acima definido, estruturamos o presente texto de maneira a apresentar a metodologia utilizada nas pesquisas ora em discussão (próxima seção); demonstrar e discutir o processo de destruição da natureza em ambientes rurais (seção seguinte); demonstrar e discutir o processo de destruição da natureza em ambientes urbanos (seção seguinte); e a apresentação de algumas notas conclusivas da presente discussão (última seção).

\section{Metodologia}

Buscando, portanto, derrubar a tese positivista segundo a qual a conduta emocional seria uma desordem no processo de conhecimento do mundo, Sartre (2013, p. 56) argumentou que "[...] o sujeito emocionado e o objeto emocionante estão unidos numa síntese indissolúvel [visto que a] emoção é uma certa maneira de apreender o mundo", o que também foi ressaltado por Santos (2006).

Ademais, no âmbito da emoção, para o mesmo pensador acima citado, o corpo, orientado pela consciência, na perspectiva de uma "emoção sofrida", mudaria suas relações com o mundo, suscitando linguagens diferentes através das quais, por sua vez, o mundo poderia mudar. Nessa perspectiva, fazendo uma crítica à modernização ocorrida no espaço agrário do Nordeste brasileiro, à revelia das rugosidades histórico-territoriais do espaço regional, Andrade (1983) reconhecera que tal postura sempre causou traumas às populações locais, os quais devem ser considerados pela ciência.

Com efeito, fica difícil e mesmo impossível, principalmente nos tempos atuais em função da celeridade dos processos de destruição da natureza pelos imperativos da lógica técnico-instrumental capitalista neoliberal, não se horrorizar diante do que está acontecendo nos diversos ambientes tecidos em territórios rurais e urbanos do Planeta, razão pela qual se faz necessário

[...] assumir o típico comportamento empático, definível como 'observação participativa', cuja análise científica interage com os sentimentos, as emoções e a específica experiência vivida do estudioso. A abordagem teórica e o trabalho de campo não se limitam, portanto, à mera narração objetiva dos fatos, mas se imbricam [...]. Neste contexto, o trabalho do geógrafo traduz-se na compreensão dos problemas territoriais por meio do contato direto com os eventos, procurando escutar as vozes do sofrimento expressas com desespero por quem sofre o incrível adensamento de impactos ambientais... (VALLERANI, 2013, p. 16, tradução livre)

Esta observação participativa da dinâmica atual dos referidos ambientes, expressando os diversos tipos de sofrimentos atinentes à vida que neles se encontra historicamente tecida constitui um ponto de partida não somente para compreender a complexidade em termos das inter-relações entre sociedade e natureza; como também constitui um instrumento utilizado no sentido de vislumbrar perspectivas concretas de mudança da tragédia que lhes acomete.

No âmbito, portanto, desta abordagem relacional e através de um esforço interdisciplinar visando dar conta da complexidade da problemática dos ambientes territoriais, nossa abordagem argumentativa fundamenta-se em procedimentos metodológicos que julgamos necessários para dar conta do objetivo proposto neste artigo.

No que diz respeito à ideia de destruição da natureza em ambientes rurais, utilizamo-nos, em linhas gerais, dos seguintes procedimentos metodológicos, visando a gerar o mapeamento da cobertura vegetal da série analisada para 1975, 1984, 1992, 2000, 2007 e 2015: o primeiro foi o georreferenciamento das imagens de satélite (landsat 1 e 5) utilizando o Landsat 8 como referência, após o que foi realizado o recorte das cenas com base em duas microrregiões (Barreiras-BA e Santa Maria da Vitória-BA); e a seguir foi feito o mosaico que se refere ao processo para gerar uma única imagem a partir de várias cenas. Estas etapas são genericamente chamadas de pré-processamento, após as quais foi feita a segmentação da imagem e a posterior classificação, aproximando-se do resultado pretendido. Estas duas últimas etapas são chamadas genericamente de processamento. Por fim, na etapa chamada de pós-processamento foi feita a revisão e a publicação dos mapas.

No que concerte à ideia de destruição da natureza em ambientes urbanos, tem-se a apreciação das dinâmicas no território da praia do Paiva, localizada no município Cabo de Santo Agostinho, na Região Metropolitana do Recife (RMR), em Pernambuco. Utilizamo-nos dos seguintes procedimentos metodológicos: a abordagem teórica a qual se deu através da investigação de temas transversais, com o levantamento e revisão bibliográfica em livros e artigos em periódicos científicos; bem como da análise da legislação urbana e ambiental fazendo breves apreciações de sua evolução para o que se utilizou da técnica hermenêutica. Tivemos como foco os instrumentos que regulam as intervenções no ambiente local, como a lei de uso e ocupação do solo e o Plano Diretor de Desenvolvimento Urbano e Ambiental do município do Cabo de Santo Agostinho, porém relacionando-os com outros instrumentos que deveriam estar em consonância, como os artigos 182 e 183 da Constituição Federal e o Estatuto da Cidade (lei 10.257/2001). Analisamos as alterações realizadas nos instrumentos locais, para que houvesse possibilidades de intervenções na praia do Paiva, alterando sua conformação territorial e ambiental.

Para o estudo empírico foram realizadas visitas de campo a fim de perceber como vem se dando a construção do ambiente ora considerado, além de pesquisa documental. Quanto ao baldrame empírico, a percepção do lugar, do ambiente, das pessoas e de suas relações na conformação do território, destacamos que como pesquisadores, observadores críticos do ambiente e de sua realidade, compreendemos os espaços com visões dialogicamente estabelecidas. A partir de uma argúcia sensual, através da visão, audição, do olfato, do tato, pelas emoções e sensações; e concomitantemente por nosso arcabouço intelectual, com os filtros de nossa racionalidade, cognição e maneira de enxergar a realidade, a qual não nos deixa cair na tentação tão-só de 
uma análise parcial. Buscou-se, pois, dar completude, na medida de nossas limitações, à análise da realidade concreta diante das apreensões. Portanto, deixa-se claro, assim como assinala Tuan (1980, pp. 16-17), que "os objetos que percebemos são proporcionais ao tamanho do nosso corpo, à acuidade e amplitude do nosso aparelho perceptivo e ao propósito".

Deste modo, vamos considerar ideias e imagens utilizadas nestas duas pesquisas realizadas junto ao grupo de pesquisa Movimentos Sociais e Espaço Urbano, que atua em consonância com a filosofia do Programa de Pós-Graduação em Desenvolvimento e Meio Ambiente da Universidade Federal de Pernambuco, sobre os impactos de ações antrópico-antropogênicas em diferentes ambientes do território nordestino: rural (BRANDÃO, 2017) e urbano (PONTES, 2017).

\section{A destruição da natureza em ambientes rurais}

Pretende-se demonstrar, através da série dos mapas, confeccionados, que o bioma Cerrado - a partir da análise do que acontece no Oeste da Bahia - vem sendo destruído de maneira cada vez mais célere e intensa em função do avanço da agricultura moderna ligada ao agronegócio. E isto, baseado em um modelo de uso produtivo do espaço visando precipuamente ao crescimento econômico subordinando os espaços nacionais da economia internacional às exigências do mercado globalizado, como fornecedores, no âmbito da divisão territorial do trabalho, de commodities agrícolas.

Se em 1975 (Gráfico 1, 2 e Figura 1) o referido bioma constituía um imenso território de reserva, coberto com vegetação nativa preservada (aproximadamente 90 mil km² de vegetação natural) e com atividades produtivas de subsistência vinculadas à agricultura tradicional; bastaram nove anos apenas, precisamente a partir de 1984 (Figura 1), para se observar, no Oeste da Bahia, o processo de ocupação programática com a agricultura moderna conservadora e dolorosa, muito embora a pecuária e a agricultura tradicionais ainda se mostrassem predominantes.

Gráfico 1 - Evolução das classes de cobertura vegetal $\left(\mathrm{km}^{2}\right)$

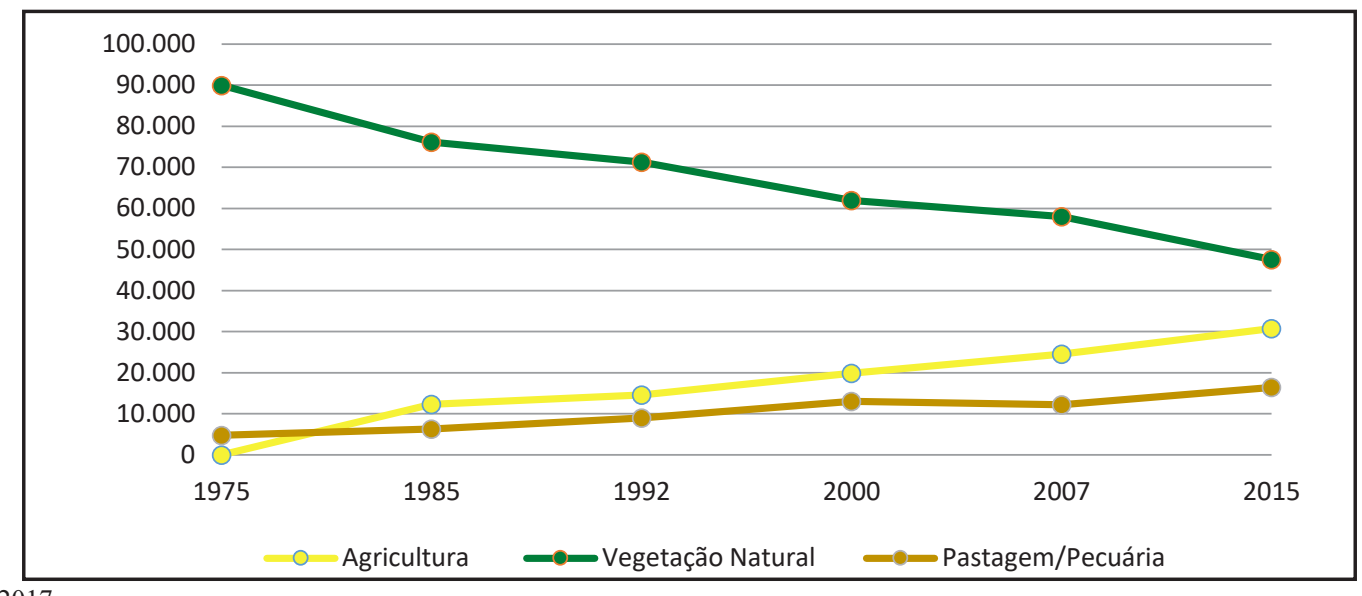

Fonte: Brandão, 2017

Gráfico 2 - Evolução das classes de cobertura vegetal (\%)

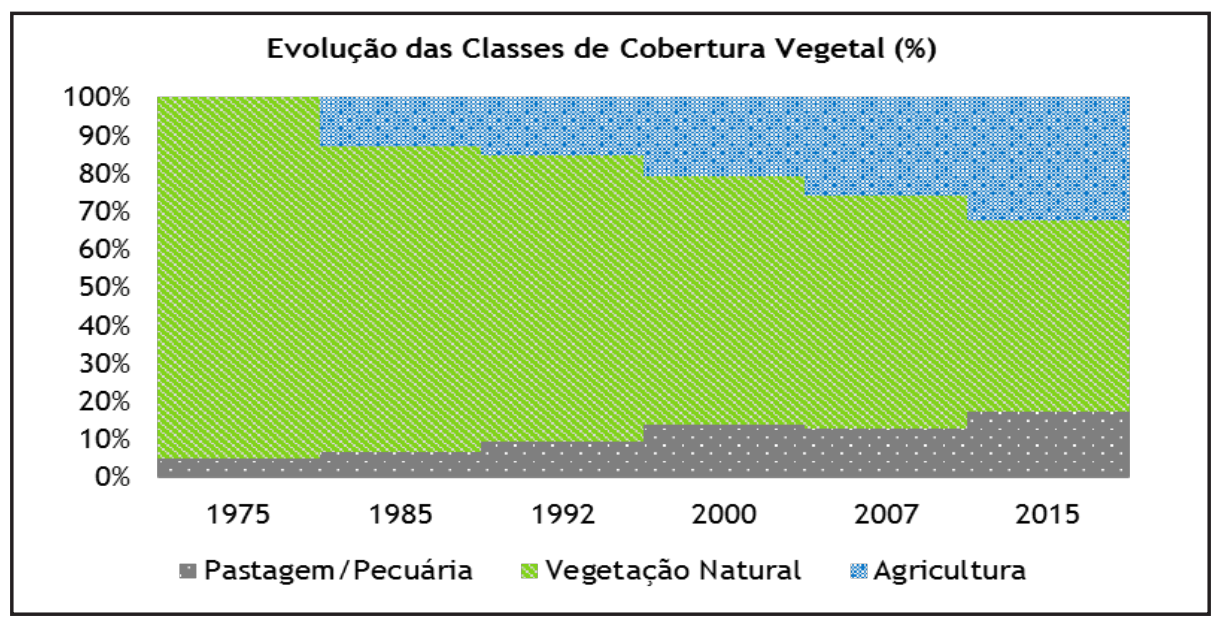


Foi partir da década de 1990 (Gráfico 1, 2 e Figura 1), entretanto, que a expansão da agricultura moderna tomou grande impulso diante do agronegócio ampliando-se nos anos 2000 (Figura 2) na área em apreço e, por sua vez, chegando a substituir a agricultura tradicional; processo de expansão territorial que, deste então, não parou de acontecer, sobretudo em função do aprimoramento cada vez maior das forças sociais de destruição da natureza e com o apoio do Estado visando ao crescimento econômico a todo custo, sob o modelo exportador de commodities agrícolas, baseado na reprimarização da economia brasileira.

Nota-se, então, que o processo trágico de destruição da natureza no bioma Cerrado, lamentavelmente, continuou a acontecer, de maneira que, em 2015 (Figura 2), mais de 40 mil km² de vegetação nativa já haviam sido visivelmente devastados; o que, simultaneamente, se replicou na perda de parte do patrimônio ambiental das paisagens (Figura 3) do referido bioma, restando alguns que precisam ser evidenciados para, ao sofrer com a ameaça que lhes acomete, sensibilizar a sociedade no sentido da sua preservação. E isto somente tomando como base de referência a região Nordeste do Brasil.

Figura 1 - Mapeamento da cobertura vegetal no bioma cerrado
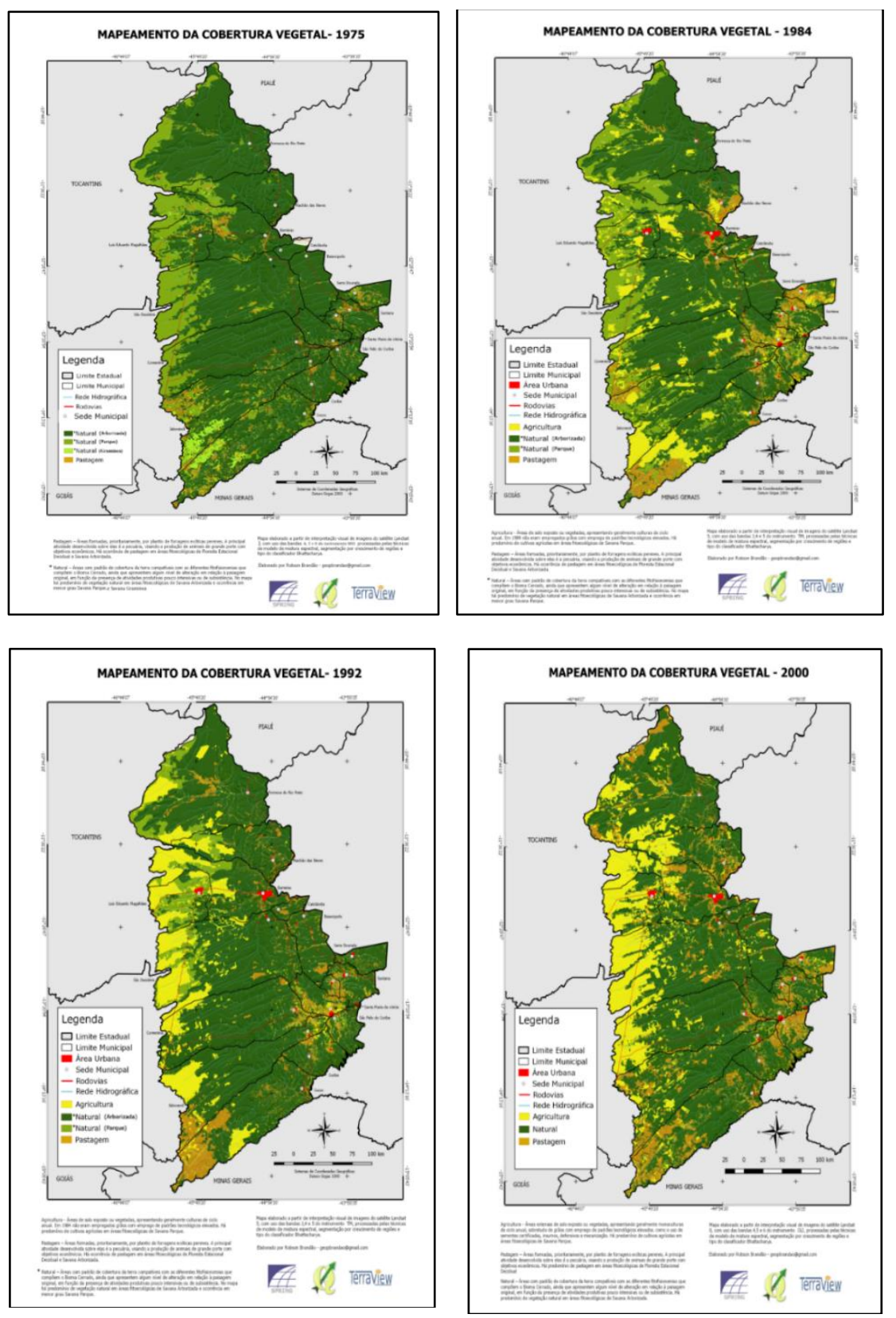

Fonte: Brandão, 2017. Nota: 1975 (mapa superior à esquerda);1984 (mapa superior à direita); 1992 (mapa inferior à esquerda); e 2000 (mapa inferior à direita). 
Figura 2 - Mapeamento da cobertura vegetal no bioma cerrado
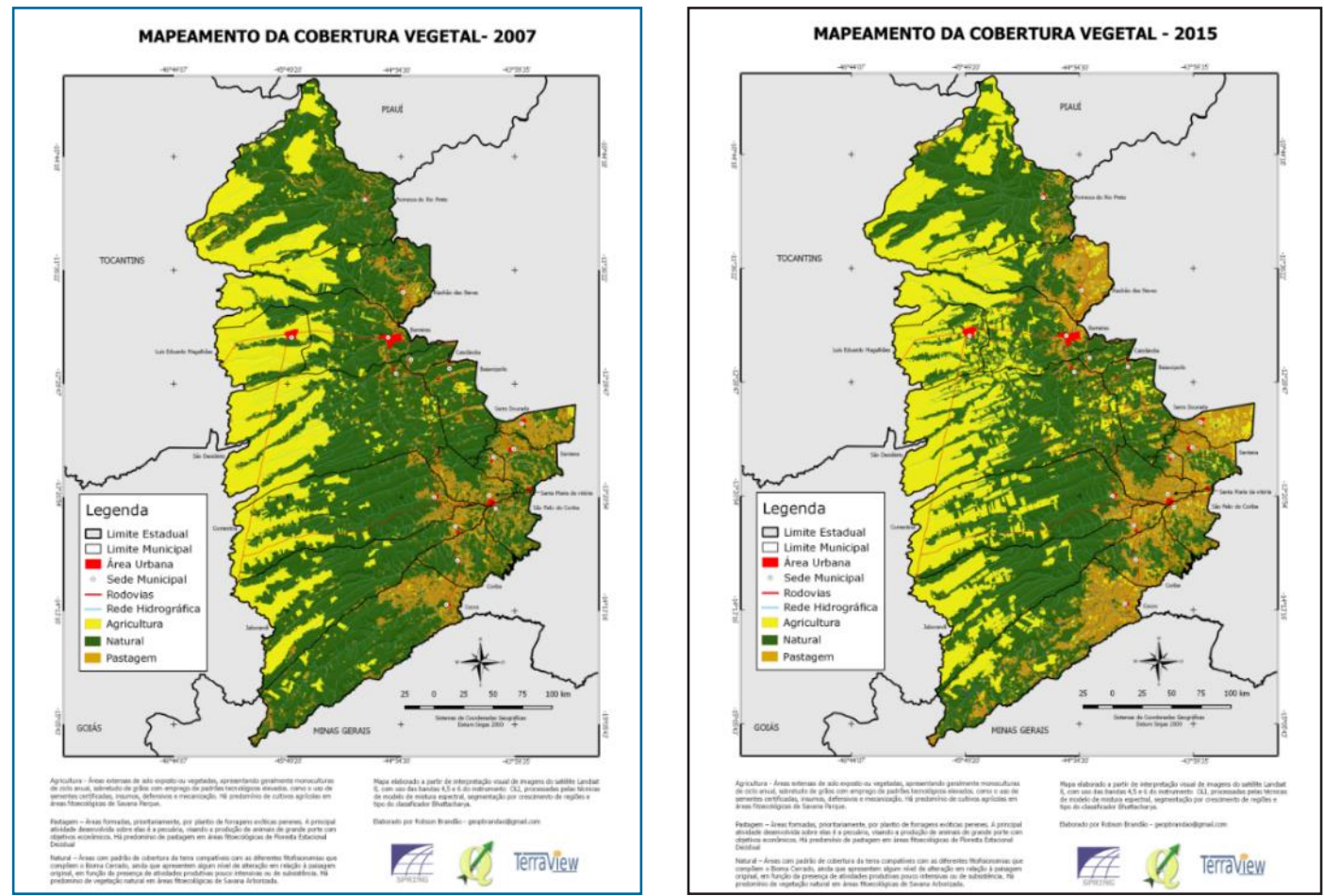

Fonte: Brandão, 2017. Nota: 2007 (mapa à esquerda); 2015 (mapa à direita)

Figura 3 - Vegetação natural, cachoeira acaba vida e arredores da cachoeira acaba vida na RPA do Oeste baiano

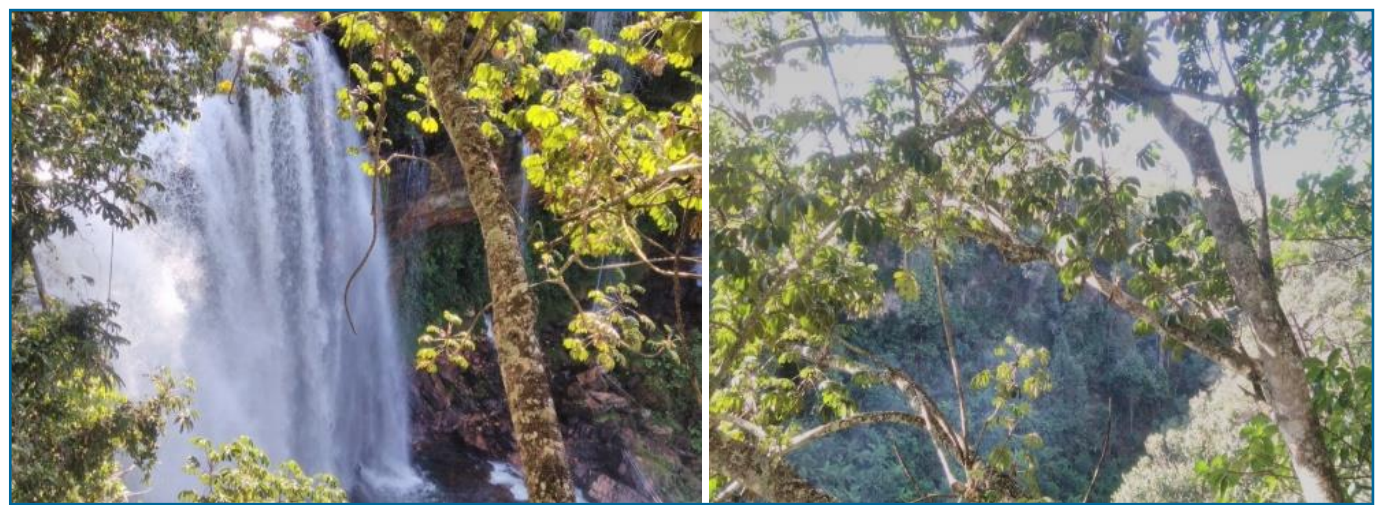

Fonte: Brandão, 2017.

Verificando-se os índices de vegetação representados pelo gráfico 3, é possível observar o comportamento da vegetação, ao longo da série temporal: assim, de 2000 até 2006 percebemos que o comportamento da cobertura vegetal nativa obteve altos níveis de vegetação verde sadia (valores próximos a 1), com pouca variação ao longo do período. Contudo, entre 2006 e 2007, o gráfico demonstra baixíssimo nível de cobertura vegetal (valores próximos a 0), representando o corte raso da vegetação nativa. A partir de 2007 percebemos que o comportamento da vegetação assume um ciclo anual que traduz exatamente o comportamento das lavouras temporárias, a exemplo dos campos de plantio de soja, algodão e milho predominantes na região (Figura 4).

Ademais, destacamos que não estamos perdendo apenas a cobertura vegetal nativa, mas, simultaneamente, comunidades - indígenas e quilombolas - e suas respectivas culturas que foram desterritorializadas no curso da expansão da agricultura moderna globalizada no bioma Cerrado. Tema que os autores deste artigo pretendem discutir em outro momento. 
Gráfico 3 - Índice de vegetação

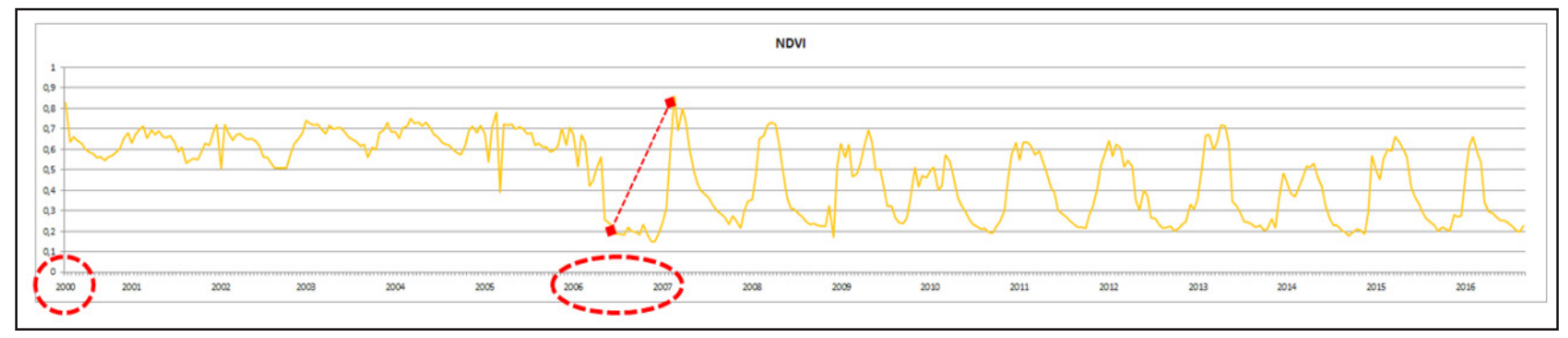

Fonte: EMBRAPA, 2016

Figura 4 - Atividades produtivas
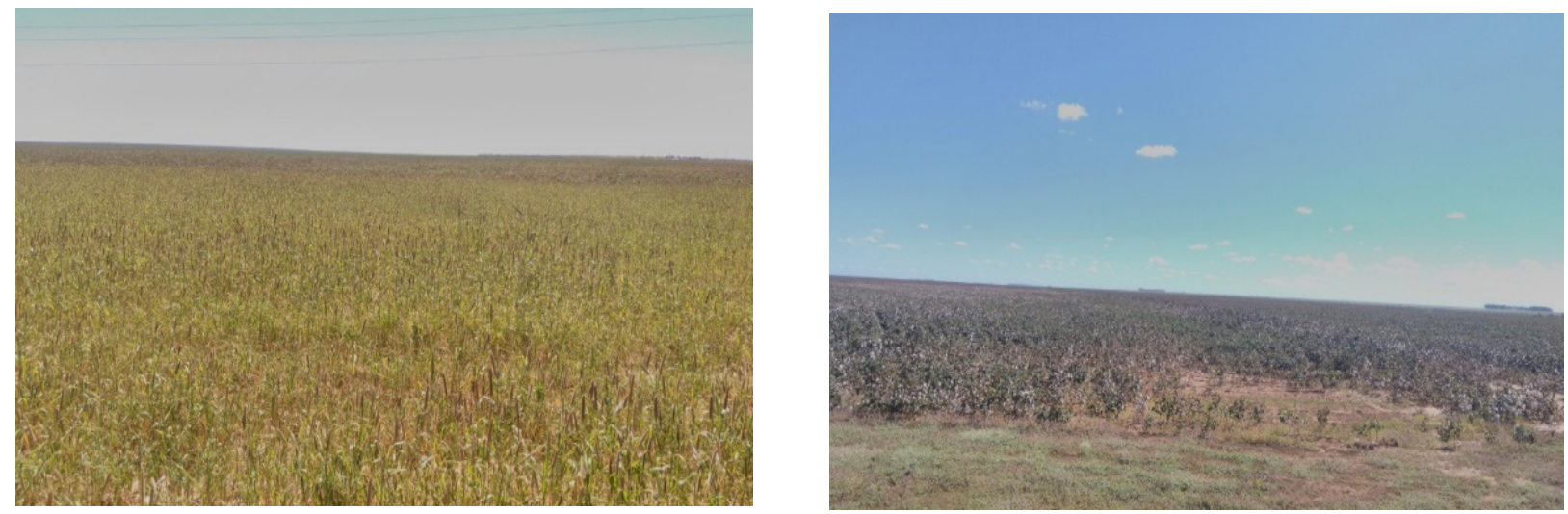

Fonte: Brandão, 2017. Nota: soja (foto à esquerda) e algodão (foto à direita).

Nota-se na figura 5, que a agricultura moderna está cada vez mais expandindo-se não somente na região do Oeste da Bahia; mas simultaneamente, nas áreas que compreendem o bioma Cerrados da região nordestina, consolidando a fronteira agrícola do MATOPIBA. Esta sigla, formada pelas letras iniciais dos estados federados Maranhão, Tocantins, Piauí e Bahia, refere-se a uma das regiões da expansão do agronegócio no Brasil.

Diante da continuidade desta tragédia ambiental, chamamos a atenção para a necessidade de fazer valer as conquistas realizadas em termos de se pensar e praticar ações mais próximas do que se defende como sustentável. O que deve ser levado em conta a fim de controlar de maneira mais eficaz as forças sociais destruidoras da natureza, retomando a perspectiva de outra racionalidade, talvez a ambiental, baseada nas forças sábias da natureza.

E esta retomada pode ter seu início começando pelo respeito a tudo o que existe no território a exemplo dos elementos da natureza - da vegetação natural pertencente ao bioma Cerrado no caso ora analisado - libertando-se da prática de enxergar o espaço sempre como algo a se ganhar e conquistar permanentemente, fazendo valer os interesses alienígenas alienadores vinculados à lógica da racionalidade técnico-instrumental puramente capitalista.

Portanto, nesta seção, buscamos investigar uma atividade destruidora da natureza, com um aporte teórico-prático e, historicamente comprovado, de profunda e intensiva deformação do espaço geográfico. Isto através da formação e expansão de atividades agrícolas científicas globalizadas no Oeste da Bahia, patrocinada através de incentivos da parte do Estado, usando o espaço, na perspectiva de preenchê-lo com objetos fixos alheio ao lugar para fazer valer o puro crescimento econômico. Assim, o que se cogitou propor neste trabalho, busca, no âmbito da política e da ética, contribuir na mudança da trágica situação do bioma Cerrado.

Para isto, o planejamento do desenvolvimento sob a responsabilidade do Estado deveria estar comprometido não, predominantemente, com o crescimento econômico, mas, ao mesmo tempo, territorial em sua complexidade; enquanto processo de elevação dos padrões de qualidade da vida e, para tanto, como processo de mobilização da sociedade, visando a definir para que perspectiva em termos de "produção" o território deve ser usado.

Para o que, aliás, deve-se investir na formulação de uma linguagem que se contraponha a de que o agronegócio vem se utilizando para fazer valer os seus interesses - "agro é tech, agro é pop" (Figura 6) - inerentes à racionalidade hegemônica, desmitificando a fábula do agronegócio de maneira a elucidar a sua verdadeira natureza.

Nesta perspectiva, portanto, ressaltamos a necessidade urgente de pensarmos e refletirmos acerca da fábula do desenvolvimento - sustentada pelo discurso que se utiliza da linguagem do agronegócio como uma atividade moderna que precisa ser expandida permanentemente de maneira célere e intensa, colocando-a como caminho ao desenvolvimento territorial da região e do país. E isso, desmitificando-a, a fim de que possamos recuperar a possibilidade de fazer cumprir a promessa incompleta do iluminismo, lembrada por Passet (2002), da "gestão cuidadosa" do ambiente para evitar a sua dilapidação. 
Figura 5 - Quantidade produzida de soja

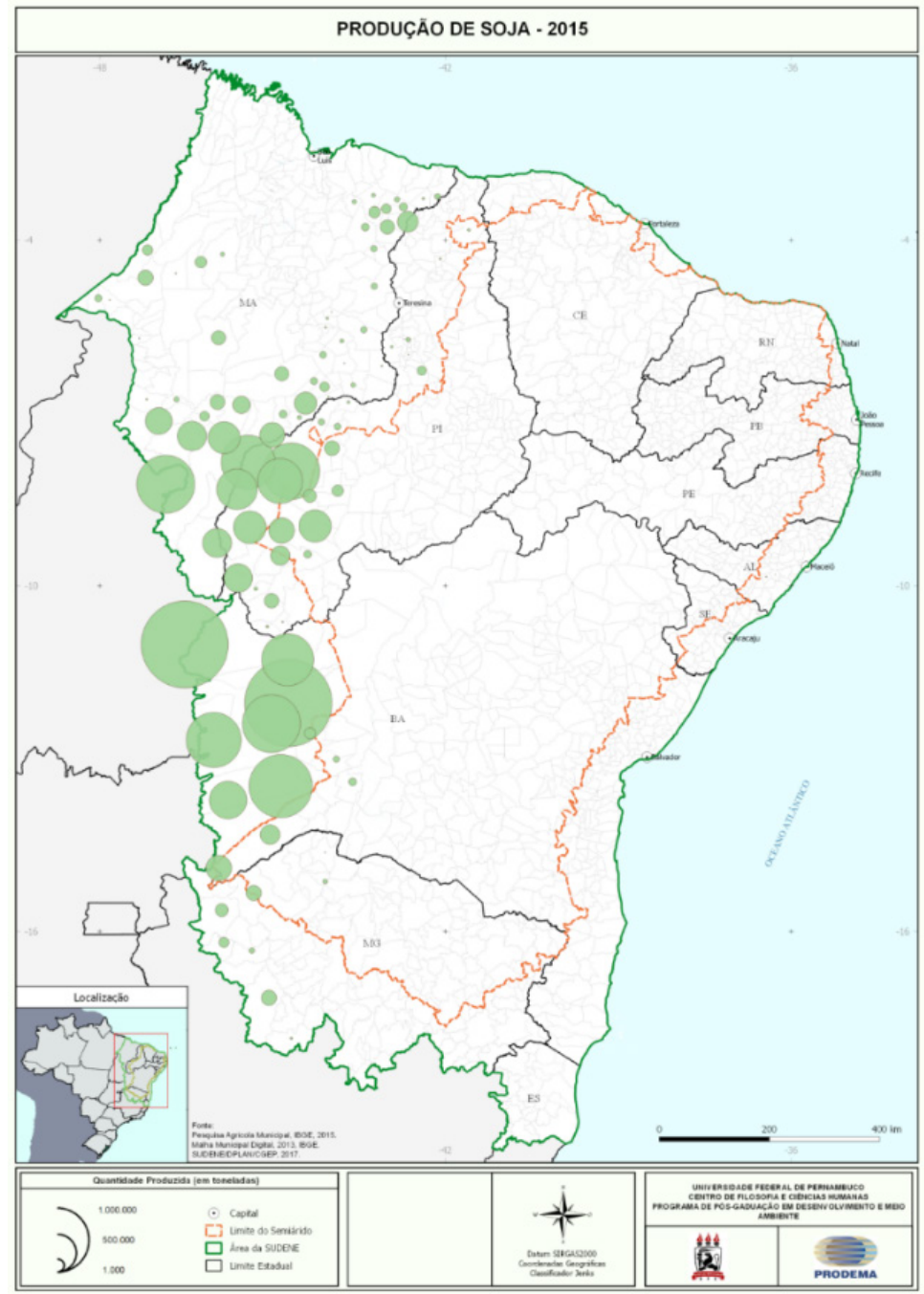

Fonte: IBGE, 2017. Elaboração de Brandão, 2017

Figura 6 - Linguagem do discurso do agronegócio como fator de desenvolvimento

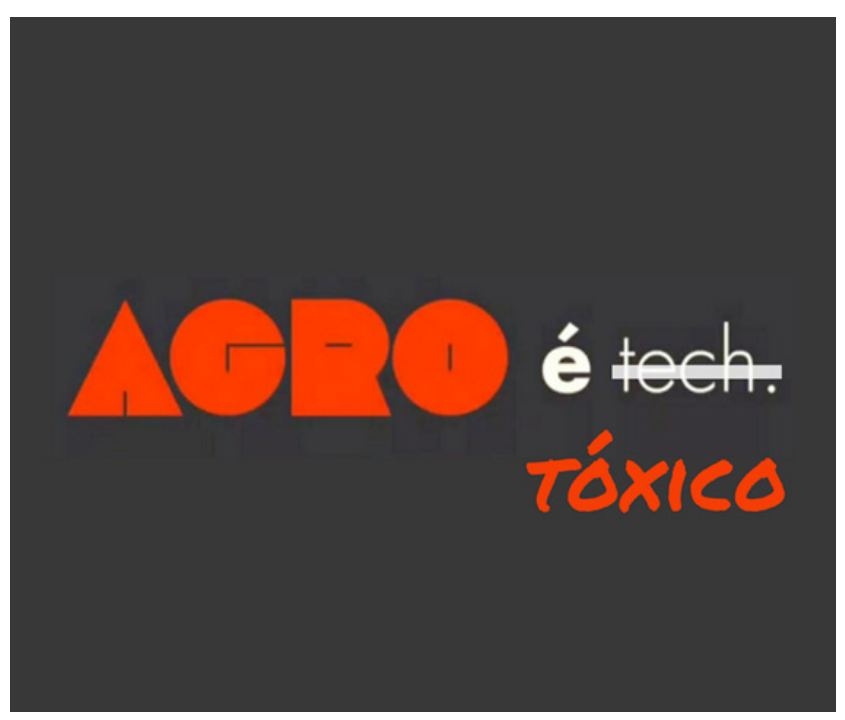




\section{A destruição da natureza em ambientes urbanos}

A praia do Paiva localiza-se no extremo norte litorâneo do município Cabo de Santo Agostinho (Figura 7), na Região Metropolitana do Recife (RMR), o qual é composto por nove praias (Paiva, Itapuama, Xaréu, Enseadas, Gaibu, Calhetas, Paraíso, Suape e a praia do Cabo de Santo Agostinho), totalizando 24,1 km de litoral. A área total da praia do Paiva possui cerca de 1.050 hectares, com $8,6 \mathrm{~km}$ de praia (portanto, cerca de $35 \%$ do litoral do município), $5 \mathrm{~km}$ de rios e 500 hectares de mata atlântica e mangue. Esta área se destaca por ser de significativa diversidade ambiental, onde se localizam: o estuário dos rios Pirapama e Jaboatão; ecossistema de manguezal, que cobre a margem dos rios; a restinga, que se localiza entre a faixa de praia e um remanescente de Mata Atlântica ao fundo; e os recifes de corais que formam piscinas naturais na baixa-mar. Ademais, na porção sul da Praia localiza-se a Mata de Camaçari, definida, segundo o Sistema Estadual de Unidades de Conservação (SEUC), como Reserva de Floresta Urbana (FURB), portanto, importante área de captação de águas subterrâneas, o que contribui para a manutenção dos mananciais que abastecem parcialmente a porção sul da RMR. Possui localização privilegiada, tanto pelos aspectos naturais, quanto pela proximidade de importantes equipamentos urbanos da RMR: Aeroporto Internacional dos Guararapes (a 14 km), Complexo Industrial Portuário de Suape (a 17 km), Centro Histórico do Recife (a 26 Km).

Figura 7 - Localização da praia do Paiva

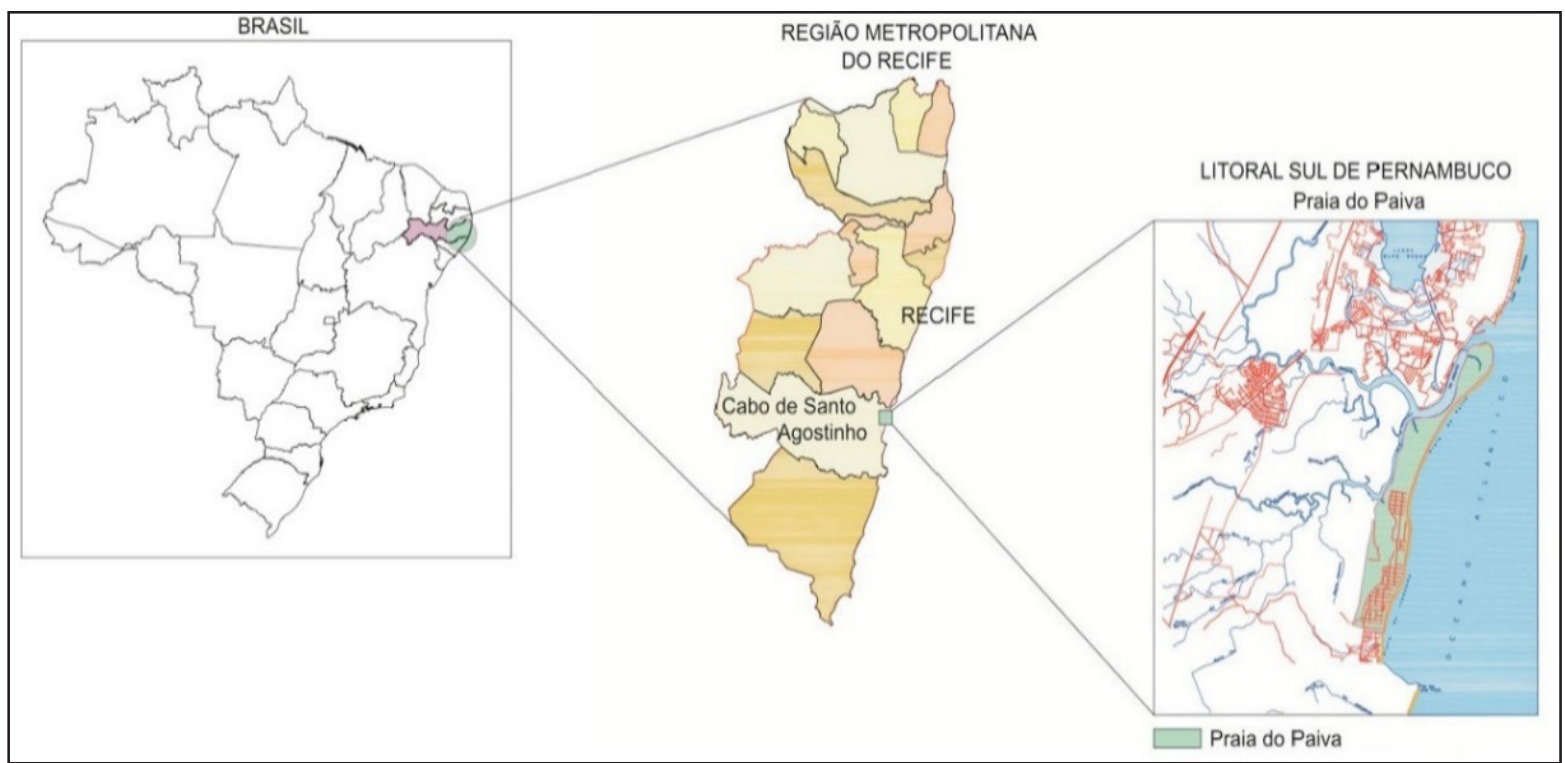

Fonte: Pires Advogados e Consultores, EIA/RIMA do Projeto Modificativo do Loteamento Praia do Paiva (2006), com modificações

Deste modo, trata-se de um ambiente urbano de considerável diversidade natural, numa área de conexão entre a RMR e o Complexo Industrial Portuário de Suape (CIPS). Características que, num contexto de avanço da urbanização, das estratégias de empreendedorismo urbano (HARVEY, 2005a) e de destruição da natureza, tornaram-na território estratégico aos interesses capitalistas, mais especificamente ao setor imobiliário. A propósito, este tem sido o modus operandi de apropriação dos ambientes pelos produtores hegemônicos do espaço urbano (liderados pelos proprietários fundiários e promotores imobiliários, detentores do capital terra e capital financeiro, respectivamente), atuantes com a conivência legitimadora do Estado, o qual molda as balizas regulatórias de intervenção no meio urbano seguindo, em grande medida, os seus interesses. Quanto a este aspecto ressaltamos a afirmação de Corrêa (1995, p. 12), segundo a qual

[...] a ação destes (atores) se faz dentro de um marco jurídico que regula a atuação deles. Este marco não é neutro, refletindo o interesse dominante (que os favorece), e constituindo-se, em muitos casos, em uma retórica ambígua, que permite que haja transgressões de acordo com os interesses dos (atores) dominantes.

A localização privilegiada desta área foi prerrogativa para a transformação do ambiente da praia do Paiva, o qual aporta, desde 2007, a construção de um megaempreendimento, denominado Reserva do Paiva, que se insere in loco diante do avanço da lógica de reprodução capitalista do espaço (HARVEY, 2005a). Saltam à nossa percepção alguns dos argumentos basilares da linguagem utilizados na concepção do referido megaempreendimento: sustentabilidade, responsabilidade socioambiental, inclusão social, desenvolvimento, desenvolvimento sustentável, governança, conservação ambiental, qualidade de vida, segurança, inovação, sofisticação, exclusividade, moradia de alto padrão. Tais pressupostos puderam ser extraídos dos materiais publicitários produzidos pela Odebrecht Realizações Imobiliárias (promotor imobiliário do megaempreendimento), disponibilizados no site da Reserva do Paiva, e utilizados para a sua própria promoção, de acordo com seu Memorial Descritivo 
(ODEBRECHT, 2008, p. 3), buscando "conquistar nichos de mercado de alto padrão tanto na hotelaria e turismo, quanto no imobiliário residencial com foco no mercado local e internacional, ou seja, para primeira moradia ou para o turismo residencial".

O simulacro da sustentabilidade neste território assumiu papel central quando da aprovação do Projeto Modificativo Loteamento Praia do Paiva pelo município do Cabo, que culminou na construção do Megaempreendimento Reserva do Paiva (MRP). O que se tem percebido com intervenções deste tipo é o recrudescimento de processos que suprimem os territórios, reconfigurando as cidades, tornando-as ambientes propícios aos negócios. Em nome da "sustentabilidade", os espaços têm se tornado cada vez mais centrais para o acúmulo de capital e, ao mesmo tempo, transversos, paradoxais e subversivos ao ideário da sustentabilidade. Efeitos de uma dialética ambiental complexa. A mercadificação irrestrita propiciada pela flexibilização da acumulação, tem sido responsável pela crescente privatização do espaço e privação do amplo acesso a ambientes naturais, como também pela grande especulação imobiliária que tanto custa aos espaços urbanos devido ao déficit habitacional existente. Corrobora-se, assim, a afirmação de Harvey (2005a, p. 165) segundo a qual "[...] o significado das cidades é uma arena de perenes controvérsias [...]”. Da mesma maneira, de acordo com a constatação de Lefebvre (2006, p. 06),

Impossível pensar a cidade e o urbano modernos, enquanto obras (no sentido amplo e forte da obra de arte que transforma seus materiais) sem de início concebê-los como produtos. E isso num modo de produção definido, que ao mesmo tempo enfraquece, mostra suas consequências extremas, por vezes deixa passar 'outra coisa', ao menos como alerta (expectativa), exigência, apelo. Decerto, os ecologistas já tinham advertido e opinado: território, meio ambiente, ar e água poluídos, a natureza, essa 'matéria primeira', material da Cidade, devastada sem escrúpulos.

O viés dado à confecção do projeto do MRP e a sua aprovação - do mesmo modo que aconteceu no caso da expansão do agronegócio no bioma Cerrado - pelo Estado, que ensejam numa nova dinâmica ambiental na praia do Paiva, ratifica, portanto, o atual modelo de (des)envolvimento. O que deriva do imperativo da inserção competitiva das cidades e dos seus ambientes, inclusive pela via da afirmação dos atributos naturais associados à linguagem do discurso da sustentabilidade, para atrair investimentos em favor do "desenvolvimento". Este processo, que nada mais é do que crescimento econômico, foi muito bem explicitado em uma obra clássica que coloca o desenvolvimento econômico como um mito, a qual, apesar de datar de 1974, traz ponderações que permanecem atuais.

A evidência à qual não podemos escapar é que em nossa civilização a criação de valor econômico provoca, na grande maioria dos casos, processos irreversíveis de degradação do mundo físico. O economista limita o seu campo de observação a processos parciais, pretendendo ignorar que esses processos provocam crescentes modificações no mundo físico. [...] A atitude ingênua consiste em imaginar que problemas dessa ordem serão solucionados necessariamente pelo progresso tecnológico, como se a atual aceleração do processo tecnológico não estivesse contribuindo para agravá-los. Não se trata de especular se teoricamente a ciência e a técnica capacitam o homem para solucionar este ou aquele problema criado por nossa civilização. Trata-se apenas de reconhecer que o que chamamos de criação de valor econômico tem como contrapartida processos irreversíveis no mundo físico, cujas consequência tratamos de ignorar (FURTADO, 2001, p. 12-13).

Note-se que tal entendimento do desenvolvimento engendra dinâmicas que perpetuam uma relação instrumental entre sociedade e natureza. A Figura 8 representa um pouco da conformação da "nova" realidade do ambiente da praia do Paiva.

Figura 8 - Comparativo do ambiente da praia do Paiva antes de 2006 (A) e depois do Megaempreendimento Reserva do Paiva, em 2014 (B)
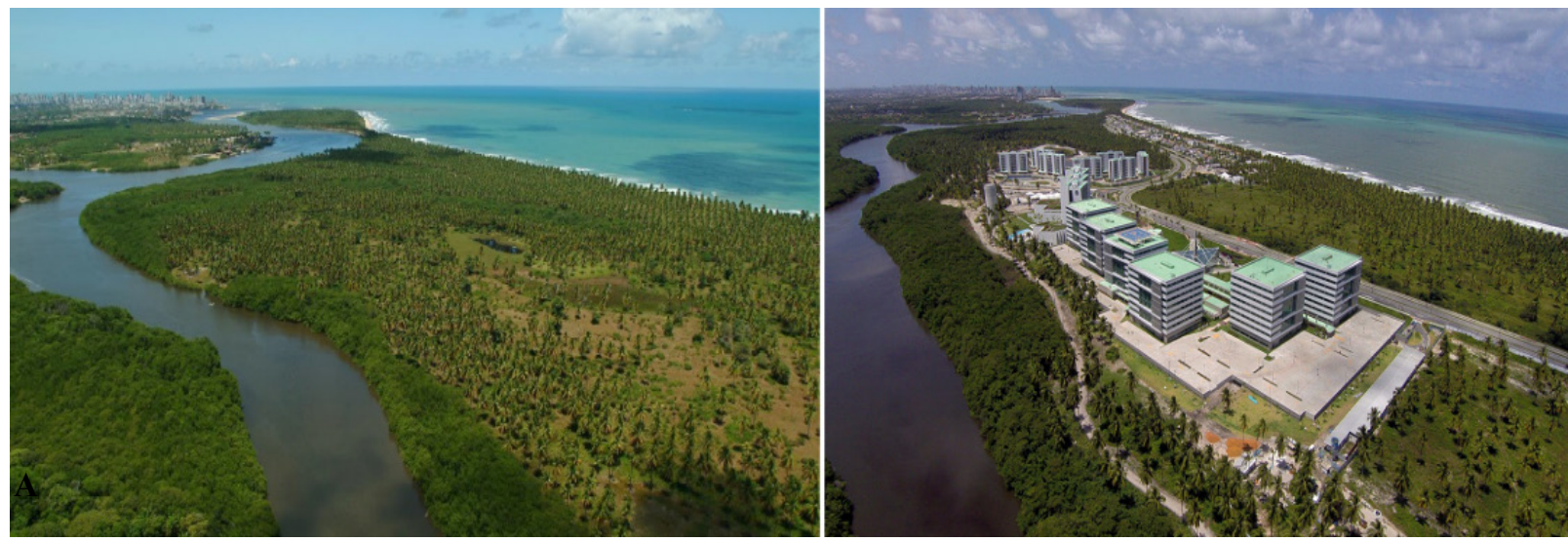

Fonte: Odebrecht Realizações Imobiliárias (2014), com modificações 
Numa consideração que se apoia nas ideias de Santos (2006), os elementos fixos ${ }^{1}$ da praia do Paiva favoreceram ações que modificaram o lugar e desencadearam novos fluxos ${ }^{2}$, os quais recriaram as condições sociais, redefiniram o ambiente, modificaram a significação e o valor dos fixos, assim como alteraram a intensidade dos fluxos. Sendo assim, retrataremos alguns atributos físicos (Figura 9) e de ocupação do solo da praia do Paiva ${ }^{3}$, sem esgotá-los, mas tentando transmitir a imagem das peculiaridades que contribuíram para o seu tecido ambiental.

\section{Figura 9 - Características naturais da praia do Paiva antes da construção do MRP}
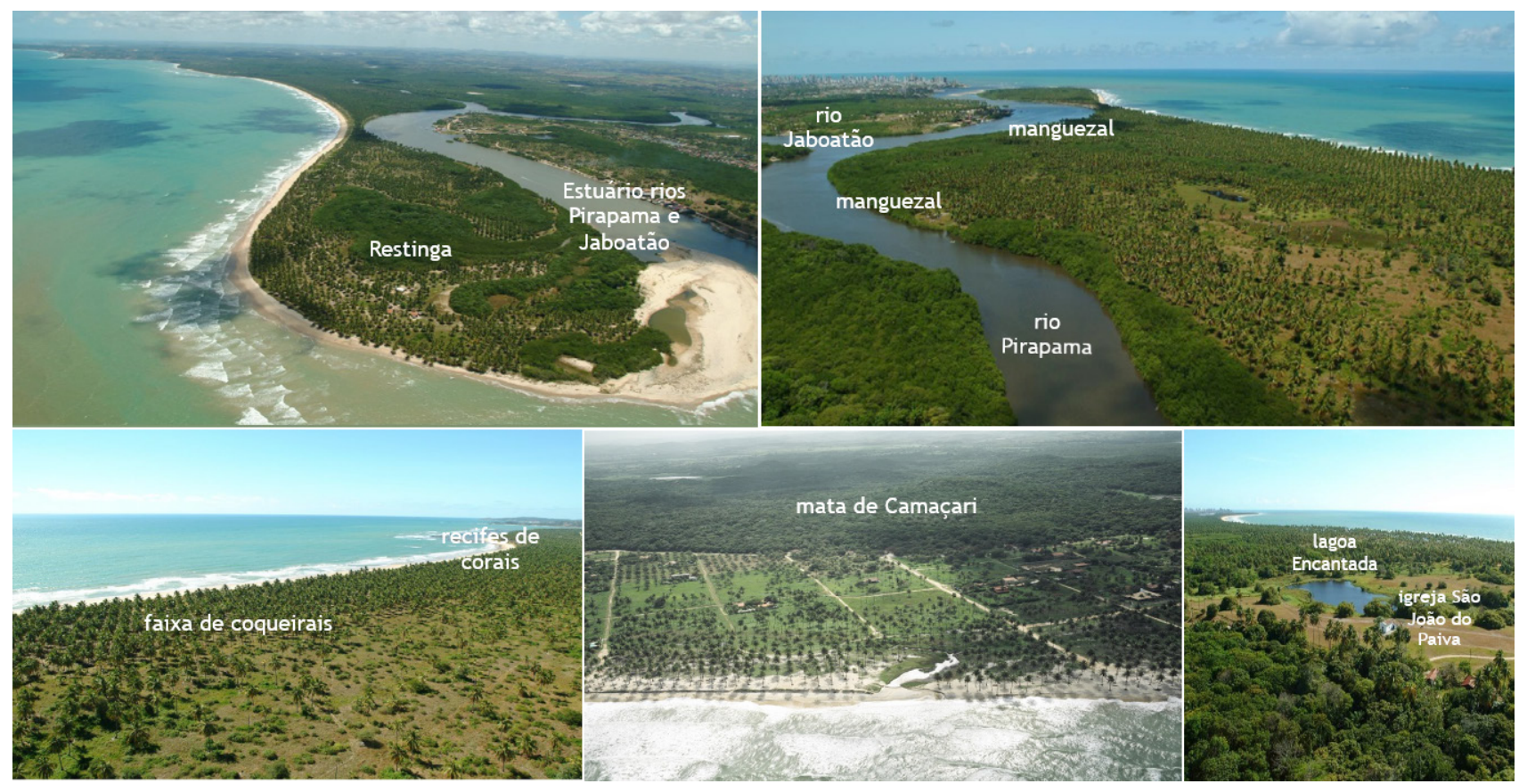

Fonte: Odebrecht Realizações Imobiliárias (2006), com modificações.

A praia do Paiva, portanto, retrata a riqueza natural presente no litoral sul da RMR, revelando um ambiente diverso e repleto de grande beleza. De modo geral, o ambiente natural local apresenta área de várzea e terraço aluvial a oeste; área de recarga de aquífero e um remanescente de mata atlântica que se trata de reserva ecológica, além de recifes de corais, na porção sul; área de manguezal, estuário e restinga, ao norte; e a faixa de praia que percorre toda a sua extensão.

Andrade e Lins (1984)4 esclarecem que o Paiva se trata de uma praia holocênica, marcada por recifes de arenito calcífero, fossilífero e areias quartzosas marinhas, com os solos dos mangues provindos de sedimentos argilosos e argilo-siltosos ou ainda de misturas de material de natureza orgânica com sedimentos arenosos. Caracteriza-se, portanto, pela presença de solos halomórficos, ou seja, condicionados pela salinidade da água no estuário afogado e sujeito aos fluxos e refluxos das marés oceânicas. A vegetação natural é constituída pela mata perenifólia das restingas e terraços litorâneos, oriundos de sedimentos costeiros, com solos excessivamente drenados e com baixa fertilidade natural. Apresenta culturas de coqueiros, coco-da-baía, cajueiros, mangueiras, fruta-pão, cará e mandioca, muitas destas degradadas devido à implantação do Megaempreendimento Reserva do Paiva (MRP).

$\mathrm{Na}$ enseada do Paiva havia espessas camadas de sedimentos caulínicos, cuja exploração ainda é realizada para o fabrico de porcelanas, “[...] as argilas, areias e cascalhos eram matérias-primas para a indústria cerâmica, utilizadas para fabricação de tijolos, telhas, manilhas, cerâmica branca e refratários" (ANDRADE e LINS, 1984, p. 29). Até hoje estas matérias-primas são utilizadas pela Oficina Brennand, onde há exposição e venda das peças em cerâmica feitas pelo artista plástico Francisco Brennand (que pertence à família dos proprietários fundiários, Ricardo e Cornélio Brennand). Destarte, as atividades produtivas predominantes na área eram extrativas e de plantio, configurando baixo adensamento populacional.

Mais ao sudoeste da praia do Paiva acha-se a Mata de Camaçari, que se encontra numa área de tabuleiro costeiro; trata-se de uma mata tropical subperenifólia, recoberta por diversas espécies, mas predominantemente, por espécies de Mata Atlân-

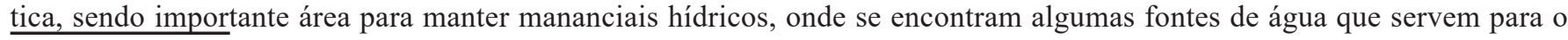
1 Entenda-se como fixos os objetos construídos e os elementos naturais presentes no ambiente da praia do Paiva.

2 Entenda-se como fluxos as ações e dinâmicas surgidas a partir do uso e das atividades desenvolvidas neste ambiente.

3 Adotamos a terminologia "praia" do Paiva por entender que tal expressão é mais "palatável” à compreensão do público leitor, pela possibilidade de maior abrangência compreensiva. Deste modo, ao utilizá-la buscamos retratar o conjunto, o ambiente em que se dão os fenômenos e as dinâmicas ora estudados.

Ainda que saibamos que a designação "praia" expressa, de forma literal, um fenômeno geomorfológico caracterizado pela acumulação de sedimentos não consolidados periférica a um corpo hídrico. No contexto aqui empregado, ela também abarca elementos e processos da dinâmica social de ocupação desse espaço. 4 Destaca-se que tais autores foram responsáveis por um profundo estudo das características naturais e de ocupação de todo o curso do rio Pirapama, que compõe o ambiente da Praia do Paiva. 
abastecimento da região.

Tal como ocorre, também, no Oeste da Bahia, destacamos a atuação conjunta e a articulação política entre o Estado e os atores privados para concretização das intervenções urbanas, por meio da confecção ou modificação de instrumentos legais. As modificações realizadas nas leis do município do Cabo de Santo Agostinho, a fim de dar legalidade à construção do MRP, ratificam intervenções que vêm a recrudescer a fragmentação territorial, privar o acesso aos ambientes de acordo com o poder aquisitivo e privatizá-los. Transformam o território aumentando a desigualdade e a possibilidade de crescimento da tensão e do conflito sociais, além de corroborarem com a destruição da natureza na área da praia do Paiva (Figura 10).

Figura 10 - Praia do Paiva, com destaque para o processo intenso de urbanização

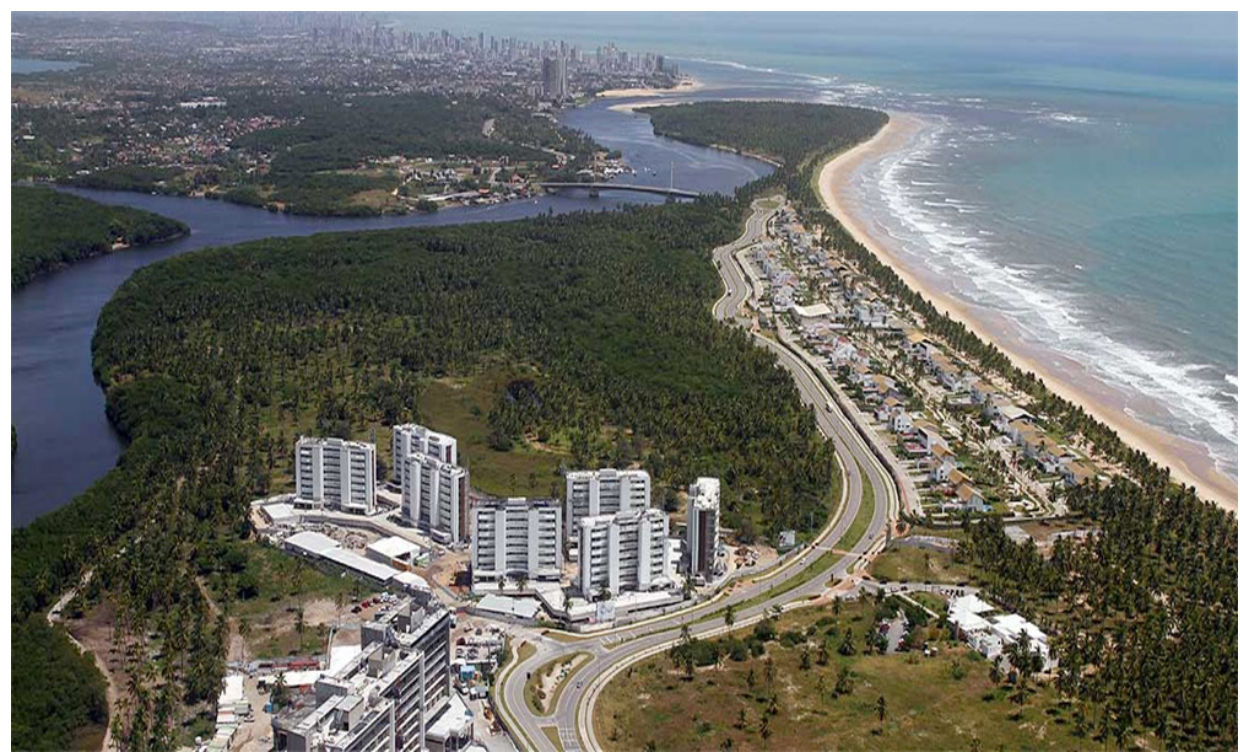

Fonte: Odebrecht Realizações Imobiliárias (2014), com modificações.

Quanto a isto, Santos (2006, p. 39) nos alertara para o fato de que "cria-se uma configuração territorial que é cada vez mais o resultado de uma produção histórica e tende a uma negação da Natureza natural, substituindo-a por uma natureza inteiramente humanizada". E ainda, de acordo com Souza (2013, p. 143),

[...] a reprodução [...] de um padrão de organização caracterizado por grandes disparidades de acesso à infraestrutura (urbana) [...], por estigmatização social e espacial e por práticas espaciais de 'afastamento, separação, segregamento', a frustração, o rancor e a resistência não tenderão a desaparecer (grifo nosso).

Quanto aos instrumentos legais, as atividades sobre a área submetiam-se à Lei de Uso e Ocupação do Solo (LUOS) - Lei n 2.179 de abril de 2004 (CABO, 2004), a qual impunha parâmetros urbanísticos de acordo com a zona de ocupação e suas características ambientais. O ambiente da praia do Paiva, segundo o macrozoneamento da LUOS, foi classificado, àquela época, como Zona de Expansão Urbana de Interesse Ambiental II, prevendo restrições quanto ao uso e à ocupação do solo, tais como: taxa de ocupação máxima de $10 \%$, gabarito máximo de $9 \mathrm{~m}$, número máximo de 2 pavimentos, taxa mínima de solo natural de $80 \%$ da área, lote mínimo de $10.000 \mathrm{~m}^{2}$.

Ainda de acordo com a referida lei, em seu art. 18, "a Zona de Expansão Urbana de Interesse Ambiental II configura-se por uma ocupação de baixa densidade construtiva, de modo a conservar suas características ambientais, sendo permitida a ocupação com granjas, chácaras e atividades de lazer". Na seção II, Art. 67, inciso primeiro, considerou-se como áreas non aedificandi: "I - as margens dos rios, canais, lagoas e açudes existentes no município, conforme foi disciplinado na legislação em vigor". Por suas características naturais e por se tratar de uma área de grande diversidade ambiental - como já exposto -, a praia do Paiva foi outrora considerada como tal. Entretanto, atualmente quem dá guarida às intervenções no ambiente urbano do Cabo é a lei n².926/2006, que instituiu o Plano Diretor de Desenvolvimento Urbano e Ambiental, a qual revogou a LUOS.

Sem embargo, presumidamente em favor de interesses rentistas visando à geração de valores tanto para o lucro - por parte dos proprietários fundiários e promotores imobiliários - quanto para a auferição de receitas advindas de impostos e tributos por parte do Estado - que o ambiente da praia do Paiva, então, passou a ser considerado como Zona Especial de Turismo, Lazer e Moradia da Reserva do Paiva (ZETLM-RP) (a IX Zona Especial do município), por meio da lei n $\mathrm{n}^{\circ} 2.387 / 2007$. A propósito, esta lei alterou o parágrafo $1^{\circ}$ do art. 46 (que criou a IX Zona Especial) e acresceu o artigo 56-A (que definiu os parâmetros urbanísticos da nova Zona Especial) no Plano Diretor de Desenvolvimento Urbano e Ambiental. E ainda, através da lei ${ }^{\circ}$ 2.926/2012, alterou-se o artigo 56-A do Plano Diretor, a fim de proporcionar novos padrões urbanísticos à ZETLM-RP. O que 
mostra um arranjo institucional que garante o atendimento de interesses específicos.

Vale realçar que o parágrafo $2^{\circ}$ do art. 46 do Plano Diretor deixa claro que "Fica autorizado o Poder Executivo a declarar outras áreas, como especiais, sempre que a dinâmica territorial assim o exigir ou para atender a diretrizes de planos específicos" (CABO, 2006). Assim, percebemos uma propensa flexibilização da legislação urbana e ambiental em atendimento aos interesses do mercado. O que também mostra o poder exercido pelos atores privados sobre o público nesta relação, diante de um cenário de competitividade para a atração de investimentos.

Destarte, destacamos algumas das diretrizes gerais da Política Urbana no Brasil, preceituadas pelo Estatuto da Cidade (lei $\mathrm{n}^{\mathrm{o}}$ 10.257/2001), art. $2^{\circ}$ incisos I, II, III e IV,

I - garantia do direito a cidades sustentáveis, entendido como o direito à terra urbana, à moradia, ao saneamento ambiental, à infraestrutura urbana, ao transporte e aos serviços públicos, ao trabalho e ao lazer, para as presentes e futuras gerações;

II - gestão democrática por meio da participação da população e de associações representativas dos vários segmentos da comunidade na formulação, execução e acompanhamento de planos, programas e projetos de desenvolvimento urbano;

III - cooperação entre os governos, a iniciativa privada e os demais setores da sociedade no processo de urbanização, em atendimento ao interesse social; IV - planejamento do desenvolvimento das cidades, da distribuição espacial da população e das atividades econômicas do Município e do território sob sua área de influência, de modo a evitar e corrigir as distorções do crescimento urbano e seus efeitos negativos sobre o meio ambiente (BRASIL, 2001).

Como também, destacamos, ainda, alguns dos objetivos (art. $2^{\circ}$, incisos I, II, III e IV, VIII, XI e XII) e das diretrizes (art. $3^{\circ}$, incisos I, II e III) da Política Urbana a nível municipal, dadas pelo Plano Diretor de Desenvolvimento Urbano e Ambiental do Cabo de Santo Agostinho,

Art. $2^{\circ}$ São objetivos da política urbana e ambiental do Cabo de Santo Agostinho:

I - o pleno desenvolvimento das funções sociais da Cidade do Cabo de Santo Agostinho, entendida na sua real dimensão metropolitana;

II - o bem-estar e a melhoria da qualidade de vida da sua população total, integrada pela população residente, trabalhadores, usuários e visitantes;

III - o uso socialmente justo e ecologicamente equilibrado do território do Município;

IV - a inclusão social e a redução da pobreza através de políticas públicas, municipais e metropolitanas, de desenvolvimento sustentável;

VIII - a definição da configuração urbanística da cidade, orientando a produção, ocupação e uso do espaço urbano, tendo como parâmetro a função social da cidade;

XI - a efetiva participação dos diversos agentes públicos e privados nos processos de planejamento e gestão do desenvolvimento urbano e ambiental e de implantação da política urbana e ambiental;

XII - ampliação e valorização de espaços públicos de uso coletivo.

Art. $3^{\circ}$ São diretrizes da política urbana e ambiental do Cabo de Santo Agostinho:

I - a ordenação do território para o conjunto da comunidade, sem exclusão ou discriminação de quaisquer segmentos ou classes sociais, e sua valorização como espaço coletivo do contexto metropolitano;

II - o pleno aproveitamento do potencial urbanístico-ambiental da cidade, assegurando o uso coletivo dos seus espaços, recursos e amenidades, como bens coletivos acessíveis a todos os cidadãos;

III - a promoção do desenvolvimento urbano e ambiental, como responsabilidade do Estado e da Sociedade, com o Governo Municipal exercendo o papel de articulador do processo de desenvolvimento e da redistribuição não regressiva dos seus custos e benefícios (CABO DE SANTO AGOSTINHO, 2006);

Tais indicativos servem para balizar e nortear a atuação do poder público no ambiente, direta ou indiretamente, de maneira a regular e intermediar os diversos interesses dos atores sociais. Tais instrumentos circunscrevem, assim, uma política urbana bem construída bastante custosa aos movimentos sociais organizados para que fosse aprovada com este teor, constituindo-se como grande conquista. No entanto, ela foi mal executada e debilmente cumprida, pois há manifesto conflito entre a teoria (letras da lei) e a prática (ações para cumpri-las).

Em que pese os aspectos positivos dessa legislação, lamentavelmente, ainda não refletem, a contento, as dinâmicas urbanas que buscam disciplinar. Pois, ainda que construídas para que fossem postas como protagonistas na normalização das ações no ambiente, estas são utilizadas em favor de intervenções que terminam por instrumentalizá-las para o uso do ambiente como mercadoria, tal como também está acontecendo no bioma Cerrado. Apesar de diversos instrumentos terem sido criados para facilitar e estimular o uso das Políticas Urbanas e Ambientais de modo adequado, não se avança muito; como por exemplo a elaboração de manual para construção de Planos Diretores Participativos, pelo Ministério das Cidades, em que se estabelecem três fases para efetivar-se: a cidade que temos, a cidade que queremos e a cidade de todos.

Portanto, há um esforço para consolidar os instrumentos de ordenamento do ambiente, que se constituirão como fundamentais para a governança ambiental. No entanto, sua utilização, segundo o que preceituam, ainda pode ser considerada utópica devido à lógica que impera no ambiente, o qual tem sido transformado num ativo para atração de investimentos. E o governo - utilizandose da linguagem da governança ambiental e transformado em uma espécie de gestor de uma empresa - tem sido o aglutinador de forças para fomentar a inserção do capital que termina por se superpor e viciar os propósitos da legislação. Esta lógica tem 
transformado os territórios, as cidades, os ambientes, constituindo-os como meros produtos que responderam estritamente aos interesses dos investidores. Assim, resta claro que ainda que possuamos leis bem elaboradas que condizem com reivindicações dos movimentos sociais, para que sejam postas em prática, não se pode negligenciar as relações de poder que subrepticiamente permeiam a dinâmica dos processos sociais, os quais têm resultado na prevalência de interesses diferentes daqueles preceituados nas leis. Este imbróglio serve para demonstrar também o quão árdua é a materialização de uma governança ambiental.

As ações realizadas no sentido da reprodução do espaço urbano contradizem as aludidas normas. A praia do Paiva é um exemplo desta incongruência uma vez que está inserida numa dinâmica neoliberal em que prevalecem os interesses do setor imobiliário, em grande medida. Portanto, estes atores são os que fazem as vezes do Estado na organização do território, resultando numa crescente "privação" do espaço, como no caso aqui demonstrado, desconstruindo muitas das diretivas trazidas pelas leis.

Nesse sentido, trazemos uma das deturpações, destacando a revogação da LUOS do Cabo de Santo Agostinho, de 2004, pelo Plano Diretor, em 2006, o qual flexibilizou muitas das restrições estabelecidas e propiciou a inserção do MRP na praia. Em uma área em que - à época da LUOS, ou seja, dois anos antes (2004) - previa ocupação de baixa densidade construtiva de modo a conservar suas características ambientais, uma taxa mínima de solo natural de $80 \%$ da área e taxa de ocupação máxima de $10 \%$. O que deixa clara a intencionalidade de um outro uso daquele espaço.

Vale ainda avultar as sucessivas alterações no Plano Diretor do Cabo de Santo Agostinho para atender estritamente aos interesses dos desenvolvedores do MRP. Revela-se, portanto, as fragilidades dos instrumentos que se propõem em favor de todos, de uma pretensa governança ambiental para conformar espaços saudáveis, justos e sustentáveis, mas que não se concretizam

Figura 11 - Arranjos institucionais de governança no território da praia do Paiva

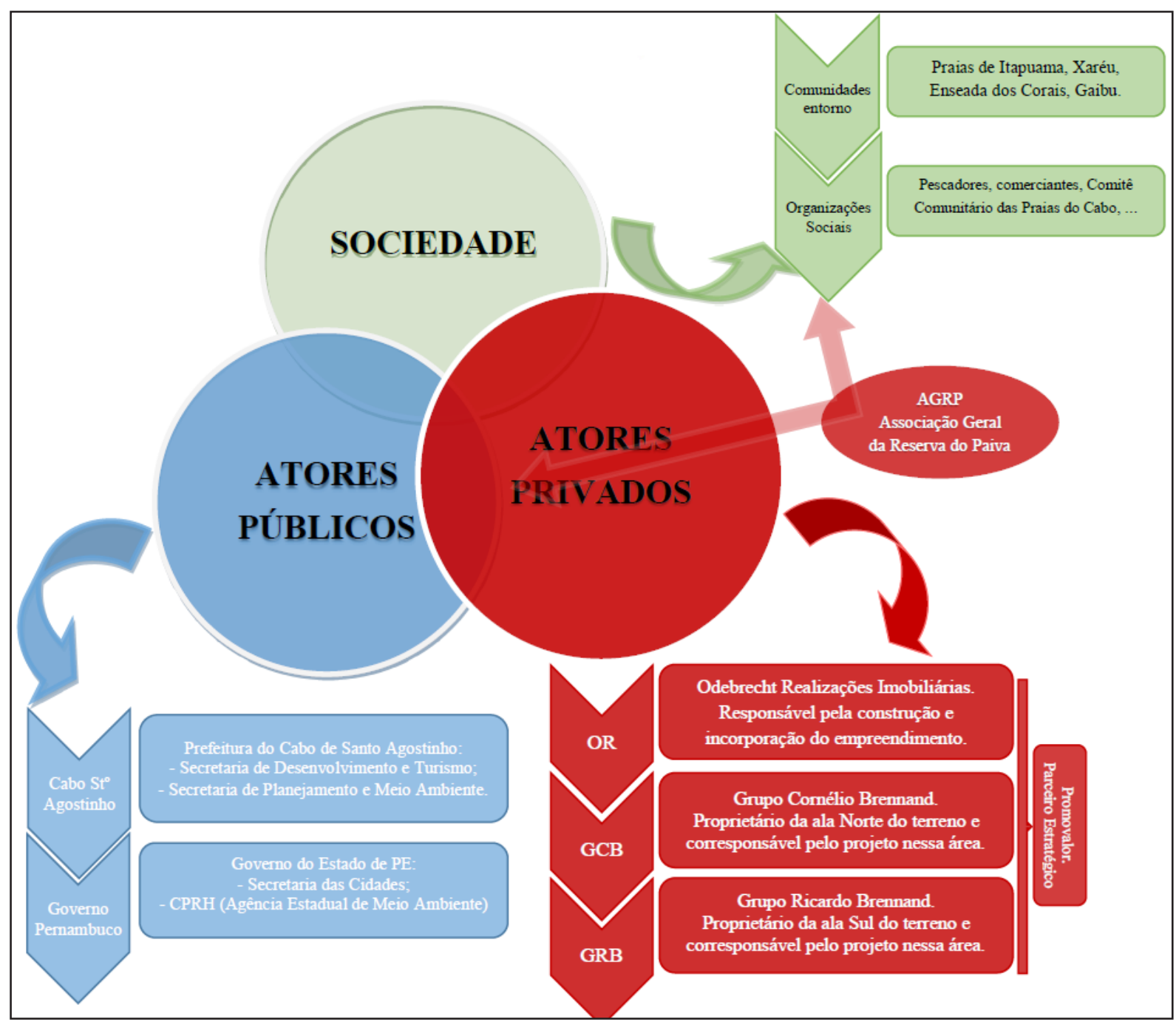

Fonte: Elaborado pelos autores

Nota: A cor forte e o tamanho dos Atores Privados e sua sobreposição aos demais demonstram o poder prevalecente que exerce, seguido pelos Atores Públicos e a menor preponderância da Sociedade no arranjo de governança presente na praia do Paiva. 
por inserirem-se num ambiente em que a tônica é a sobreposição dos interesses econômicos aos demais.

Eis que as lutas por justiça ambiental nas cidades [...] afiguram-se opostas às dinâmicas da competição interurbana, promovidas pelos atores da globalização neoliberal, inclusive pelo recurso à noção de meio ambiente favorável aos negócios [...] Essa competição interurbana, que se quer fazer sustentável pela maior mobilidade espacial atribuída aos capitais, torna mais fracos os atores sociais dotados de menor mobilidade, ou seja, os trabalhadores organizados e os governos locais. Daí a possibilidade de a multinacional decidir sobre a mudança, ou atribuir a si, por exemplo, o poder de pressionar pela mudança do traçado de uma área de proteção de manancial. Assim, em nome da obtenção de possíveis ganhos, em nome da competição, são justificadas medidas que concorrem para aumentar a segregação socioespacial, a desigualdade ambiental e o enfraquecimento político das populações residentes nas áreas empobrecidas (ACSELRAD, 2009, p. 33).

Percebemos que, no ambiente da praia do Paiva, a proposta de uma pretensa "governança ambiental" se deu após a concretização da construção do MRP. Ou seja, não houve discussão com a sociedade sobre o projeto antes de ser aprovado, não houve consulta à população sobre tal intervenção, que por isto é divulgada como benéfica, destacando-se os aspectos positivos e omitindo os negativos. Deste modo, apontamos esquematicamente a proporção dos arranjos institucionais de governança identificados na praia do Paiva, conforme a Figura 11. Destarte, seguiu-se o que é exigido para atender à legalidade, fazendo deste processo um jogo5 de quimeras quanto à participação, à democracia e à governança.

Quanto aos arranjos institucionais na praia do Paiva, percebemos que há a prevalência dos interesses dos atores privados, porque dotados da moeda de troca capital - tentamos retratar por seu tamanho e opacidade, os atores privados sobrepondo-se aos demais - enquanto os atores públicos mostram-se subservientes, respondendo às demandas dos atores privados e permitindo suas ações sem maiores resistências. À sociedade, resta a articulação para agir defendendo seus interesses, reivindicando aos atores públicos e privados a absorção de suas demandas e interesses - tentamos retratar pela sua maior transparência e por se localizar parcialmente encoberta pelos demais atores. Em menor força, à sociedade relega-se a oferta de trabalho e renda (constituintes da retórica do desenvolvimento) e uma pretensa participação, apenas para dar aparências de uma relação equilibrada entre os interesses, o que constitui a retórica da governança ambiental.

Retratamos, por fim, o caso da Festa da Lavadeira, uma tradicional expressão cultural pernambucana realizada no dia $1^{\circ}$ de maio, feriado do dia do trabalhador, surgida na praia do Paiva por volta do ano de 1987 e lá realizada por mais de 20 anos.

Figura 12 - Festa da Lavadeira, na praia do Paiva (2008)

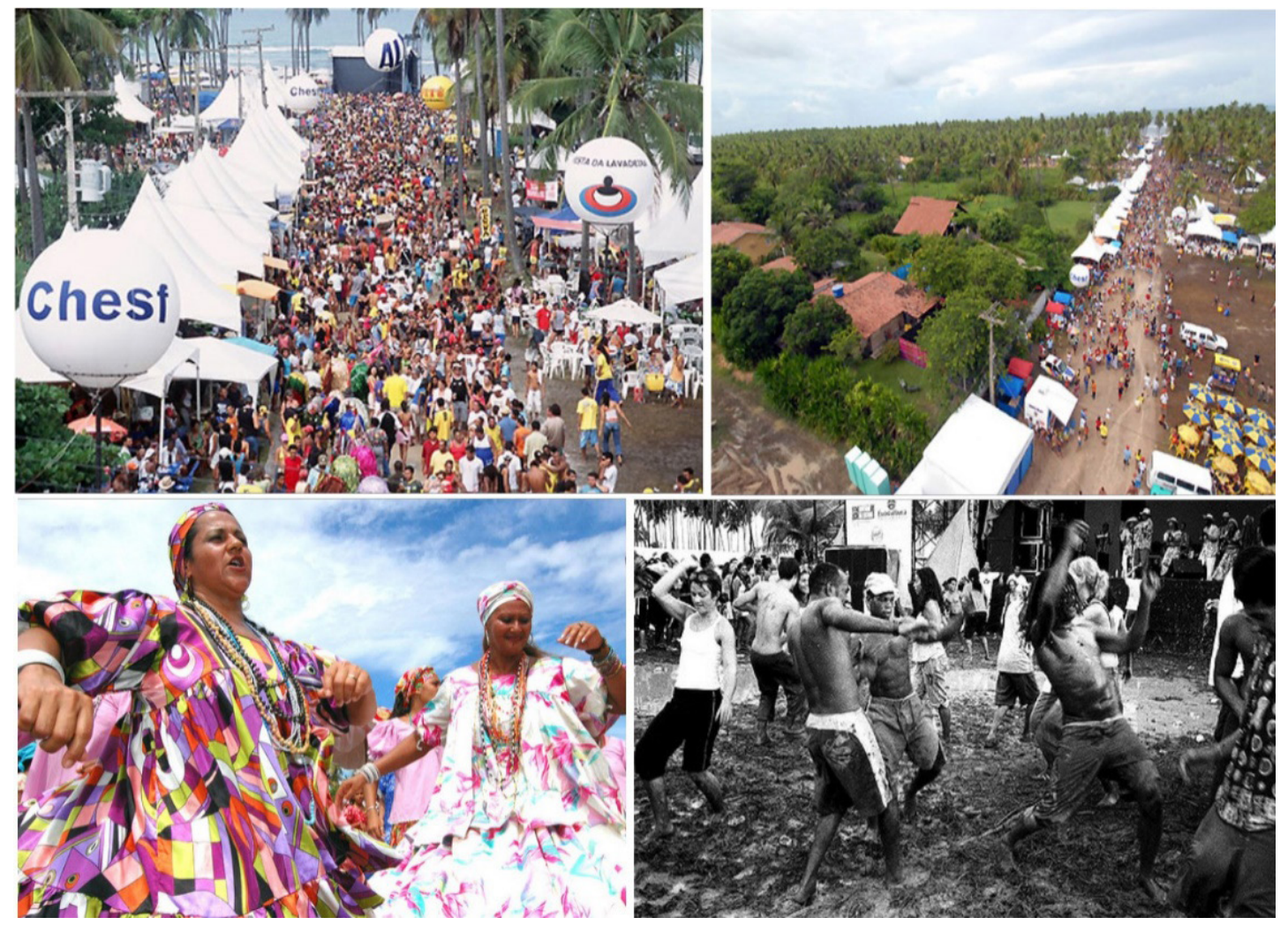

Fotos: Acervo pessoal dos autores

\footnotetext{
5 Aludimos a palavra "jogo", pois consideramos que a forma com que se constitui a "participação popular" nas instâncias de decisões, na verdade, se mostra como apenas uma eufemização, uma didática que tem servido para apaziguar os conflitos de interesses, já que se faz valer, na maior parte dos casos, os interesses dos atores hegemônicos. Quanto a isto, sugere-se a leitura de Leal, Suely. "Fetiche" da Participação Popular: novas práticas de planejamento, gestão e governança democrática no Recife - Brasil. Recife: Ed. CEPE, 2004.
} 
Manifestação que surgiu de maneira espontânea, foi sendo fortalecida pela identificação do povo para com ela, pois congregava a diversidade cultural do estado de Pernambuco e da região Nordeste, sendo um encontro de diversas outras manifestações culturais, religiosas e artísticas, com raízes em expressões populares, negras e indígenas. Sua importância e tradição foi assentida através da incorporação ao calendário turístico cultural do estado e ao calendário turístico cultural da cidade do Cabo de Santo Agostinho, além de ter recebido prêmios como: Rodrigo Melo Franco - IPHAN, em 1988; Culturas Populares do SID/ Ministério da Cultura, em 2007; Rodrigo Melo Franco - IPHAN, em 2008; Patrimônio Imaterial e Cultural de Pernambuco; e Patrimônio Imaterial e Cultural do Cabo de Santo Agostinho (BLOG FESTA DA LAVADEIRA, 2014).

A Festa da Lavadeira vinha crescendo ano após ano, com maior adesão de grupos culturais e artísticos a cada edição, além do aumento no número de frequentadores por seu caráter popular (Figura12). Isto, como reflexo da escassez de festas que reúnam tamanha diversidade cultural existente em nossa região. Da Festa participam grupos de maracatu, afoxé, ciranda, coco, rabeca, pife, samba de roda, pastoril, mazurca, pretinhas do congo, forró de oito baixos, frevo, troças e escolas de samba, vindos de outras cidades de Pernambuco, como Petrolina, Agrestina, Arcoverde e Olinda, bem como de outros estados como Alagoas e Bahia (BLOG FESTA DA LAVADEIRA, 2014).

A festa, inclusive, possui regulamentação através de lei $n^{\circ}$ 2.015/2002 que dá ao município obrigação em atender todas as necessidades atinentes ao seu funcionamento. Esta lei também dá atribuições ao município quanto às festividades de São Cosme e Damião, Paixão de Cristo e a Festa do Coco de Pontezinha, ratificando a importância destas manifestações para a cidade e a população. Quanto à Festa da Lavadeira, destacamos o art. $2^{\circ}$, incisos I e II da referida lei que traz a seguinte redação,

I - Garantir espaço destinado à Festa da Lavadeira, localizado na área verde em frente a quadra 124 e a faixa de terreno denominada 'institucional', do loteamento da praia do Paiva, como de uso exclusivo no dia primeiro de maio;

II - O espaço referido acima não poderá sofrer qualquer alteração seja paisagística ou qualquer obra, construção ou utilização que venha prejudicar a realização da Festa da Lavadeira (CABO DE SANTO AGOSTINHO, 2002).

No entanto, originada e realizada na praia do Paiva por 24 anos, a Festa da Lavadeira teve como algoz o MRP, pois este foi o responsável por retirá-la a partir de 2012 do território onde tradicionalmente se realizava. A Festa da Lavadeira passou a sofrer forte resistência por parte dos empreendedores e do governo quando da aprovação do Projeto Modificativo do Loteamento Praia do Paiva, em 2007, resistindo até 2011.

Diante de uma realidade territorial complexa e contraditória, de instrumentalização da natureza, concebendo-a como tãosomente objetos a serem dominados, a serviço da ideia de progresso, desconsiderando e suprimindo as complexas inter-relações existentes, conformam-se novas dinâmicas no território da praia do Paiva. No ambiente, onde se acham intentos de um 'progresso’ fundamentado em ideias deturpadas de desenvolvimento e governança ambiental, podemos perceber a insipiência destes propósitos e o enraizamento de uma relação sociedade-natureza alienada, constituindo-se na tragédia que aqui tentamos aclarar.

\section{Conclusão e considerações finais}

Não obstante as especificidades inerentes aos ambientes tecidos no meio rural e aquelas tecidas no meio urbano, no geral, a tragédia ambiental ora retomada é resultado de uma mesma lógica, ou seja, a da racionalidade técnico-instrumental do capitalismo - hoje neoliberal - pela qual se usa os diversos elementos da natureza como meros recursos econômicos, mercadificando-os, retirando-lhes a aura de bens coletivos.

Ao viverem, os homens e as mulheres impactam na natureza, razão pela qual, reiteramos, não há como viver sem impactar na natureza, e isto porque a natureza constitui parte intrínseca de qualquer ser vivo na Terra. Neste sentido, como dizia Elisée Reclus, ainda no século XIX, vale ressaltar que "o homem é a natureza consciente de ser natureza", muito embora tenha-se afastado cada vez mais desta condição essencial à sua existência como ser vivo.

Uma das raízes do problema inerente à tragédia que vem acometendo os diversos ambientes na Terra, para nós, reside no fato de que os homens e as mulheres foram-se afastando cada vez mais da chamada "primeira natureza", artificializando a sua própria natureza, sob os interesses da racionalidade inerente à lógica técnico-instrumental capitalista.

Nesta perspectiva, não se respeita a complexidade da vida que existe nos diversos territórios que despertam os interesses das classes sociais hegemônicas atreladas aos imperativos supracitados, suscitando a predominância das forças destruidoras da terra que desagregam os seus ambientes vividos de maneira trágica.

Criticando esta forma de pensar e atuar no espaço, Jean Brunhes, no início do século XX, chamara a nossa atenção para a necessidade urgente de controlar os impulsos destruidores da natureza a fim de fortalecer as forças sábias da natureza - cujos atores poderíamos citar os seguintes: Estado, consciência social, movimentos ambientalistas, etc. - sugerindo uma perspectiva de "sábia economia da terra" para se contrapor à "economia destrutiva da terra".

Sob os imperativos dessa racionalidade - que concebe a natureza como um espaço a ser permanentemente preenchido e dominado - delineiam-se reações que, tomando consciência da tragédia em curso, podem contribuir para a mudança no pensar 
e atuar no mundo. Com o que podemos rejeitar a produção de espaços, preponderantemente, como fator de acumulação de capitais, destruindo tudo o que se acha à sua frente, visando, ao contrário, criar possibilidades para concretizar a promessa da gestão ambiental cuidadosa, que preserve a natureza.

Desse modo, urge superar a lógica da formação territorial brasileira, baseada preponderantemente, no uso da natureza como mercadoria, considerando-a como um "bem" de/para todo(a)s, respeitando e dialogando com a diversidade de tudo o que existe no espaço, no âmbito de uma perspectiva de equilíbrio entre sociedade e natureza.

Em outras palavras, urge abandonar a prática do uso do território "a ser permanentemente preenchido", respeitando as suas rugosidades histórico-culturais, com o que se evitará que, como pensara Leroy (2010), os “territórios do capital” continuem violando os "territórios do povo", aguçando ainda mais as consequências trágicas que, lamentavelmente, estamos presenciando nos dias que correm.

\section{Referências}

ABBAGNANO N. Dicionário de filosofia. 6a ed. São Paulo: Martins Fontes; 2012.

AB’ SABER A. Os domínios de natureza no Brasil. Potencialidades paisagísticas. São Paulo: Ateliê Editorial; 2003.

ACSELRAD H, MELLO CCA, BEZERRA GN. O que é Justiça Ambiental? Rio de Janeiro: Garamond; 2009.

ANDRADE, MC. Tradição e mudança: a organização do espaço rural e urbano na área de irrigação do Submédio São Francisco. Rio de Janeiro: Zahar Editores; 1983.

ANDRADE GO, LINS RC. Pirapama: um estudo geográfico e histórico. Recife: Massangana; 1984.

BLOG FESTA DA LAVADEIRA [Internet]. [cited 2011 abr 19]. Available from: http://festadalavadeira.blogspot.com.br.

BRANDÃO RJ. A última fronteira do bioma Cerrado: análise da natureza da expansão do agronegócio no Oeste da Bahia. [dissertation in progress] Recife: Mestrado em Desenvolvimento e Meio Ambiente/UFPE; 2017.

BRASIL. Estatuto da Cidade (lei no 10.257/2001). Regulamenta os arts. 182 e 183 da Constituição Federal, estabelece diretrizes gerais da política urbana e dá outras providências. Brasília (Brasil); 2001.

BRUNHES J. Geografia humana. $1^{\text {a }}$ ed. brasileira. Rio de Janeiro: Fundo de Cultura; 1962.

CABO DE SANTO AGOSTINHO [Internet]. Lei Municipal n 2.015, de 10 de julho de 2002. Dispõe sobre a regulamentação sobre as festas comemorativas da Lavadeira, São Cosme e Damião, Paixão de Cristo e do Coco de Pontezinha, e dá outras providências. [cited 2014 out 20]. Available from: http://www.cabo.pe.gov.br/leis.asp.

CABO DE SANTO AGOSTINHO [Internet]. Lei Municipal n 2.179 de 12 de Abril de 2004. Lei de Uso e Ocupação do Solo (LUOS). [cited 2011 set 15] Available from: http://www.cabo.pe.gov.br/leis.asp.

CABO DE SANTO AGOSTINHO [Internet]. Lei Municipal n 2.360 de 29 de dezembro de 2006. Institui a Política Urbana e Ambiental e o Plano Diretor de Desenvolvimento Urbano e Ambiental do Cabo de Santo Agostinho. [cited 2011 set 15]. Available from: http://www.cabo.pe.gov.br/leis.asp.

CABO DE SANTO AGOSTINHO [Internet]. Lei Municipal n 2.387, de 30 de maio de 2007. Altera a Lei $n^{\circ} 2.360$ de 29 de dezembro de 2006, para criar a Zona Especial de Turismo, Lazer e Moradia Reserva do Paiva - ZETLM, e dá outras providências. [cited 2011 set 15]. Available from: http://www.cabo.pe.gov.br/leis.asp.

CABO DE SANTO AGOSTINHO [Internet]. Lei Municipal n ${ }^{\circ}$ 2.926, de 28 de dezembro de 2012. Altera o artigo 56-A, da lei municipal $n^{\circ} 2.360$ de 29 de dezembro de 2006, e dá outras providências. [cited 2015 mai 02]. Available from: http:// www.cabo.pe.gov.br/leis.asp.

CASTILHO, CJM. Jean Brunhes: a atualidade de um geógrafo do início do século XX. Revista Movimentos Sociais e Dinâmicas Espaciais, 2017, v.6 (n.1), 253-272. 
CASTILHO, CJM. Do (des)respeito à complexidade ambiental no processo de formação do território brasileiro. In: Galvíncio JD, Oliveira VS, Souza WM, editors. Mudança climática, sociedade, cidade e meio ambiente. Recife: Editora Universitária UFPE; 2017. p. 127-169.

CASTORIADIS C. As encruzilhadas do labirinto, III: o mundo fragmentado. Rio de Janeiro: Paz e Terra; 1992.

CORRÊA RL. O Espaço Urbano. $3^{\text {a }}$ ed. São Paulo: Ática; 1995.

FERREIRA ABH. Dicionário Aurélio da Língua Portuguesa. 5ª ed. Curitiba: Positivo; 2010.

FURTADO C. O Mito do Desenvolvimento Econômico. 3ª ed. São Paulo: Paz e Terra; 2001.

HARVEY D. A Produção Capitalista do Espaço. Szlak C, translator. São Paulo: Annablume; $2005 a$.

HARVEY D. O Novo Imperialismo. $2^{\mathrm{a}}$ ed. Sobral A, Gonçalves MS, translators. São Paulo: Edições Loyola, $2005 \mathrm{~b}$.

LEFEBVRE H. A Produção do Espaço. Pereira DB, Martins S, translators; 2006. [from original: La production de l'espace. $4^{a}$ éd. Paris: Anthropos, 2000].

LEFF E. Saber ambiental. Sustentabilidade. Racionalidade. Complexidade. Poder. Petrópolis: Vozes; 2009.

LEROY JP. Territórios do futuro: educação, meio ambiente e ação coletiva. Rio de Janeiro: Lamparina; 2010.

MORAES ACR. Meio ambiente e ciências humanas. São Paulo: Hucitec; 1997.

NIETZSCHE FW. O livro do filósofo. São Paulo: Escala; 2013.

ODEBRECHT [Internet]. Memorial Descritivo da Reserva do Paiva. [cited 2011 ago 15]. Available from: http://www.orealizacoes. com.br/Novos-Destinos-Urbanos-Conceito.aspx?id=21.

ODEBRECHT [Internet]. Galeria de Imagens Reserva do Paiva. [cited 2011 ago 11]. Available from: http://www.orealizacoes. com.br/Empreendimentos-Galeria-De-Imagens.aspx?id=33.

ODEBRECHT [Internet]. Galeria de Imagens Reserva do Paiva. [cited 2011 ago 11]. Available from: http://www.orealizacoes. com.br/Empreendimentos-Galeria-De-Imagens.aspx?id=39.

PASSET R. A ilusão neoliberal. Rio de Janeiro: Record; 2002.

PONTES BANM. Desenvolvimento e governança ambiental: em busca de uma outra práxis na dinâmica territorial da "reserva" do Paiva-PE. [dissertation] Recife: Mestrado em Desenvolvimento e Meio Ambiente/UFPE; 2017.201 p.

PORTO-GONÇALVES CW. A globalização da natureza e a natureza da globalização. Rio de Janeiro: Civilização Brasileira; 2012.

RAFFESTIN C. Frontière et souffrance. Turim: 2015.

RECLUS E. Do sentimento da natureza nas sociedades modernas. São Paulo: Expressão \& Arte; 2010.

SANTOS M. A Natureza do Espaço: técnica e tempo, razão e emoção. 4a ed. São Paulo: EdUSP; 2006.

SARTRE JP. Esboço para uma teoria das emoções. Porto Alegre: L\&PM; 2013.

SOUZA ML. Semântica Urbana e Segregação: disputa simbólica e embates políticos na cidade “empresarialista". In: Vasconcelos PA, Corrêa RL, Pintaudi SM, editors. A Cidade Contemporânea: segregação espacial. São Paulo: Contexto, 2013.

TUAN, Yi-Fu. Topofilia. Um Estudo da Percepção, Atitudes e Valores do Meio Ambiente. Oliveira L, translator. São Paulo: Difel; 1980.

VALLERANI F. Italia desnuda. Percorsi di resistenza nel Paese del cemento. Milano: Edizioni Unicopli; 2013. 


\section{Cláudio Jorge Moura de Castilho}

Departamento de Ciências Geográficas e Programa de Pós-graduação em Desenvolvimento e Meio Ambiente, Universidade Federal de Pernambuco, Brasil

Email: claudiocastilho44@gmail.com

Participação do autor:

Contribuições substanciais para a concepção do trabalho

\section{Bruno Augusto Nogueira Monteiro Pontes}

Programa de Pós-graduação em Desenvolvimento e Meio Ambiente,

Universidade Federal de Pernambuco, Brasil

Email: bruno.pontes@ufpe.br

Participação do autor:

Redigiu o trabalho ou realizou uma revisão substancial

\section{Robson José Alves Brandão}

Programa de Pós-graduação em Desenvolvimento e Meio Ambiente,

Universidade Federal de Pernambuco, Brasil

Email: geobrandao@gmail.com

Participação do autor:

Redigiu o trabalho ou realizou uma revisão substancial 